\title{
N-Desmethylclozapine, a Major Clozapine Metabolite, Acts as a Selective and Efficacious $\delta$-Opioid Agonist at Recombinant and Native Receptors
}

\author{
Pierluigi Onali*,' and Maria C Olianas' \\ 'Department of Neurosciences, Section of Biochemical Pharmacology, University of Cagliari, Cagliari, Italy
}

\begin{abstract}
The present study examined the effects of N-desmethylclozapine (NDMC), a biologically active metabolite of the atypical antipsychotic clozapine, at cloned human opioid receptors stably expressed in Chinese hamster ovary $(\mathrm{CHO})$ cells and at native opioid receptors present in NG 08 - 15 cells and rat brain. In CHO cells expressing the $\delta$-opioid receptor (CHO/DOR), NDMC behaved as a full agonist both in stimulating $\left.{ }^{35} \mathrm{~S}\right] \mathrm{GTP} \gamma \mathrm{S}$ binding $\left(\mathrm{pEC}_{50}=7.24\right)$ and in inhibiting cyclic AMP formation ( $\left.\mathrm{pEC} \mathrm{C}_{50}=6.40\right)$. NDMC inhibited $\left[{ }^{3} \mathrm{H}\right]$ naltrindole binding to $\mathrm{CHO} / \mathrm{DOR}$ membranes with competition curves that were modulated by guanine nucleotides in an agonistlike manner. Determination of intrinsic efficacies by taking into consideration both the maximal $\left.{ }^{35} \mathrm{~S}\right] \mathrm{GTP} \gamma \mathrm{S}$ binding stimulation and the extent of receptor occupancy at which half-maximal effect occurred indicated that NDMC had an efficacy value equal to $82 \%$ of that of the full $\delta$-opioid receptor agonist DPDPE, whereas clozapine and the other clozapine metabolite clozapine $N$-oxide displayed much lower levels of agonist efficacy. NDMC exhibited poor agonist activity and lower affinity at the $\kappa$-opioid receptor and was inactive at $\mu$-opioid and NOP receptors. In NGI08-15 cells, NDMC inhibited cyclic AMP formation and stimulated the phosphorylation of extracellular signal-regulated kinase $1 / 2$ by activating the endogenously expressed $\delta$-opioid receptor. Moreover, in membranes of different brain regions, NDMC stimulated $\left[{ }^{35} \mathrm{~S}\right] \mathrm{GTP} \gamma \mathrm{S}$ binding and regulated adenylyl cyclase activity and the effects were potently antagonized by naltrindole. These data demonstrate for the first time that NDMC acts as a selective and efficacious $\delta$-opioid receptor agonist and suggest that this unique property may contribute, at least in part, to the clinical actions of the atypical antipsychotic clozapine. Neuropsychopharmacology (2007) 32, 773-785. doi: I0. I038/sj.npp. I 30 I I52; published online 12 July 2006
\end{abstract}

Keywords: N-desmethylclozapine; opioid receptors; CHO cells; NG I08-I5 cells; rat brain; agonist activity

\section{INTRODUCTION}

$\mathrm{N}$-desmethylclozapine (NDMC) and clozapine $\mathrm{N}$-oxide (CNOX) are two major metabolites of the atypical antipsychotic clozapine, which lacks extrapyramidal side effects, displays high efficacy in refractory schizophrenia, improves negative symptoms, and reduces the risk of suicide in schizophrenia (Meltzer, 2002; Meltzer et al, 2003). Whereas CNOX can be rapidly re-converted to clozapine, NDMC reaches considerable plasma concentrations ranging from 49 to $140 \%$ of those of the parent compound in schizophrenic patients (Centorrino et al, 1994; Olesen et al, 1995; Aravagiri and Marder, 2001; Frazier et al, 2003) and from 50 to $220 \%$ in the rat (Baldessarini et al, 1993; Weigmann et al, 1999). In the rat brain, concentrations of

\footnotetext{
*Correspondence: Dr P Onali, Department of Neurosciences, Section of Biochemical Pharmacology, University of Cagliari, Cittadella Universitaria di Monserrato, Monserrato, Cagliari 09042, Italy, Tel: + 39070675 4321, Fax: + 39070675 4320, E-mail: onali@unica.it Received 6 February 2006; revised 2 May 2006; accepted I June 2006 Online publication: 2 June 2006 at http://www.acnp.org/citations/ Npp06020606008I/default.pdf
}

NDMC higher than those in serum have been detected following clozapine administration, indicating that the metabolite can cross the blood-brain barrier (Weigmann et al, 1999). Moreover, a higher ratio of NDMC to clozapine in plasma was found to correlate positively with clinical improvements, indicating that NDMC may contribute to the clinical efficacy of clozapine (Weiner et al, 2004).

Pharmacological studies have shown that NDMC shares the clozapine ability to bind to a large array of neurotransmitter receptor systems. Thus, NDMC was found to display high affinity for serotonin $5 \mathrm{HT}_{2 \mathrm{C}}$ and $5 \mathrm{HT}_{2 \mathrm{~A}}$ receptors, to potently block $5-\mathrm{HT}_{2 \mathrm{C}}$ receptor-stimulated phosphoinositide hydrolysis in rat choroid plexus, and to bind to striatal dopamine (DA) $D_{1}$ and $D_{2}$ receptors (Kuoppamaki et al, 1993). Following in vivo administration, NDMC increased the expression of the immediate-early gene $\mathrm{c}$-fos in rat brain with a regional specificity similar to that displayed by clozapine (Young et al, 1998).

An important feature of clozapine is its ability to bind with high affinity to acetylcholine (ACh) muscarinic receptors and to act as a mixed agonist/antagonist (Zorn et al, 1994; Zeng et al, 1997; Olianas et al, 1997, 1999; Michal 
et al, 1999). A similar property has recently been demonstrated for NDMC. Thus, in cell lines expressing the cloned human muscarinic receptor subtypes NDMC has been found to act as a partial agonist with potencies and efficacies higher than those of the parent drug (Sur et al, 2003; Weiner et al, 2004; Davies et al, 2005). In CA1 hippocampal neurons, NDMC was found to potentiate NMDA-mediated currents (Sur et al, 2003) and to induce phosphorylation of extracellular signal-regulated kinases (ERK) by activating muscarinic $M_{1}$ receptors (Weiner et al, 2004). This receptor has also been shown to mediate the increases in cortical $\mathrm{ACh}$ and DA release observed following systemic administration of NDMC in freely moving rats (Li et al, 2005). Besides stimulating muscarinic receptors, NDMC has been recently shown to act as a partial agonist in transfected cell lines overexpressing the human $\mathrm{DA} \mathrm{D}_{2}$ or $\mathrm{D}_{3}$ receptor and the $\mathrm{G}$ protein $\mathrm{Go}$, whereas clozapine behaved as an inverse agonist (Burstein et al, 2005).

Although the precise molecular mechanisms mediating the atypical antipsychotic profile of clozapine are still unknown, it is likely that both antagonist and agonist actions of the drug and its metabolite(s) at multiple neurotransmitter receptor systems may be involved (Roth et al, 2004). As NDMC is less characterized than its parent compound, the understanding of the role of NDMC in the therapeutic activity of clozapine requires the definition of its whole spectrum of pharmacological activities and molecular targets.

Previous studies have investigated the opioid system as one of the sites of action of clozapine in the brain. Chronic administration of clozapine to rats and mice increased proenkephalin mRNA expression in striatum and nucleus accumbens, dynorphin levels in substantia nigra (Angulo et al, 1990), and the density of brain $\mu$ - and $\delta$-opioid receptors (Zang et al, 1995). In mice, the acute injection of clozapine was found to produce analgesia using the tail-flick test and this effect was antagonized by naloxone and selective $\mu$ - and $\kappa$-opioid receptor antagonists (Schreiber et al, 1999). Studies in vitro have shown that clozapine inhibited $\left[{ }^{3} \mathrm{H}\right]$ Met-enkephalin binding to synaptosomeenriched fractions of rat whole brain and hippocampus with a micromolar potency (Somoza et al, 1981). In Xenopus oocytes co-injected with either the $\delta$ - or $\kappa$-opioid receptor $\mathrm{mRNA}$ and the $\mathrm{G}$ protein-activated inwardly rectifying potassium channel, Kobayashi et al (1998) reported that clozapine displayed both $\delta$ - and $\kappa$ - receptor agonist activity and suggested that this effect may contribute to the antinociceptive and proconvulsant effect of the drug. Although early studies suggested possible links between opioids and schizophrenia (Pickar et al, 1982; Schmauss and Emrich, 1985; Brizer et al, 1985; Schmauss et al, 1987; Gulya, 1990), the involvement of the opioid system in the therapeutic actions of clozapine has been generally overlooked, mostly because of the low affinity of clozapine for the opioid receptors.

In the present study we have examined the interaction of NDMC with each of the cloned human opioid receptors individually expressed in Chinese hamster ovary (CHO) cells and evaluated its receptor activity by using different functional assays. Moreover, we investigated the actions of NDMC at opioid receptors naturally expressed in NG 108-15 cells and rat brain. In each receptor system, the effects of clozapine and CNOX were also analyzed.

Part of this study has previously been presented in an abstract form (Onali and Olianas, 2004a).

\section{MATERIALS AND METHODS}

\section{Materials}

$\left[\alpha-{ }^{32} \mathrm{P}\right]$ ATP $(30-40 \mathrm{Ci} / \mathrm{mmol}),\left[2,8-{ }^{3} \mathrm{H}\right]$ cyclic AMP $(25 \mathrm{Ci} /$ $\mathrm{mmol}),\left[8^{14} \mathrm{C}\right]$ cyclic AMP $(45.1 \mathrm{mCi} / \mathrm{mmol}),\left[2,8-{ }^{3} \mathrm{H}\right]$ adenine $\quad(28.8 \mathrm{Ci} / \mathrm{mmol}), \quad\left[{ }^{35} \mathrm{~S}\right] \mathrm{GTP} \gamma \mathrm{S} \quad(1306 \mathrm{Ci} / \mathrm{mmol})$, $\left[5^{\prime}, 7^{\prime}{ }^{3} \mathrm{H}\right]$ naltrindole $\quad\left(\left[{ }^{3} \mathrm{H}\right] \mathrm{NTI}\right) \quad(20 \mathrm{Ci} / \mathrm{mmol}) \quad$ and $\left[15,16-{ }^{3} \mathrm{H}\right]$ diprenorphine $(53 \mathrm{Ci} / \mathrm{mmol})$ were obtained from Perkin-Elmer (Boston, MA, USA). FSK and GTP $\gamma S$ were from Calbiochem (San Diego, CA, USA) and Boehringer (Mannheim, Germany), respectively. Nociceptin/orphanin FQ (N/OFQ) was purchased from Neosystem (Strasbourg, France). TIPP was obtained from Bachem AG (Bubendorf, Switzerland). NDMC, (-)-U-50,488 hydrochloride (trans(-)3,4-dichloro- $N$-methyl- $N$-[2-(1-pyrrolidinyl) cyclohexyl] benzeneacetamide hydrochloride), nor-binaltorphimine dihydrochloride (nor-BNI) and CTAP were from Tocris Cookson Ltd (Avonmouth, UK). DPDPE ((2-D-penicillamine, 5-D-penicillamine)-enkephalin) was purchased from Bachem AG (Bubendorf, Switzerland). Naloxone hydrochloride was from Salars (Como, Italy). Clozapine, CNOX, NTI, DAMGO ((D-Ala ${ }^{2}-N$-methyl-Phe-Gly-ol $\left.{ }^{5}\right)$-enkephalin), and the other reagents were from Sigma RBI (St Louis, MO, USA).

\section{Cell Culture}

CHO-K1 cells (American Type Culture Collection) stably expressing the human $\delta$-opioid receptor (CHO/DOR) (2250 fmol/mg protein), $\mu$-opioid receptor-1 (CHO/MOR1) $(350 \mathrm{fmol} / \mathrm{mg}$ protein), $\kappa$-opioid receptor $(\mathrm{CHO} / \mathrm{KOR})$ (2800 fmol/mg protein), and nociceptin/orphanin FQ receptor (CHO/NOP) (400 fmol/mg protein) were generated by PolyFect (Qiagen) transfection with cDNAs cloned into pcDNA3.1 + vector (Invitrogen). The cDNAs were obtained from either UMR cDNA Resource Center (Rolla, MO, USA) or Top Gene Tec. (Montreal, Canada). Cells were grown as a monolayer culture in tissue culture flasks (Falcon) that were incubated at $37^{\circ} \mathrm{C}$ in a humidified atmosphere $\left(5 \% \mathrm{CO}_{2}\right)$ in Ham's F12 medium (GIBCO BRL) containing L-glutamine and sodium bicarbonate and supplemented with $10 \%$ heat inactivated foetal calf serum (GIBCO BRL), $0.5 \%$ penicillin/ streptomycin (GIBCO BRL) and either $350 \mu \mathrm{g} / \mathrm{ml}$ hygromycin (GIBCO BRL) for $\mathrm{CHO} / \mathrm{DOR}$ or $400 \mu \mathrm{g} / \mathrm{ml}$ geneticin (GIBCO BRL) for the other recombinant cell lines.

NG108-15 neuroblastoma $\times$ glioma hybrid cells (European Collection of Cell Cultures) were grown in DMEM supplemented with $2 \mathrm{mM}$ L-glutamine, $0.1 \mathrm{mM}$ hypoxanthine, $16 \mu \mathrm{M}$ thymidine, $0.4 \mu \mathrm{M}$ aminopterin, $0.5 \%$ penicillin/ streptomycin, and $10 \%$ heat-inactivated foetal calf serum in a humidified $95 \%$ air and $5 \% \mathrm{CO}_{2}$ at $37^{\circ} \mathrm{C}$.

\section{Cell Membrane Preparation}

Cells were grown in $100 \mathrm{~mm}$ plastic Petri dishes (Falcon), the culture medium was removed and the cells were washed 
with ice-cold phosphate-buffered saline (PBS) (pH 7.4). Thereafter, the cells were scraped into an ice-cold buffer containing $10 \mathrm{mM}$ HEPES/NaOH ( $\mathrm{pH} 7.4)$ and $1 \mathrm{mM}$ EDTA, and lysed with a Dounce tissue grinder. The cell lysate was centrifuged at $1000 \mathrm{~g}$ for $2 \mathrm{~min}$ at $4^{\circ} \mathrm{C}$. The supernatant was collected and centrifuged at $32000 \mathrm{~g}$ for $20 \mathrm{~min}$ at $4^{\circ} \mathrm{C}$. The pellet was resuspended in the homogenization buffer at a protein concentration of $1.0-1.5 \mathrm{mg} / \mathrm{ml}$ and stored in aliquots at $-80^{\circ} \mathrm{C}$.

\section{Dissection of Rat Brain Regions and Membrane Preparation}

Male Sprague-Dawley rats (200-300 g) were used. Animals were maintained in a $12 \mathrm{~h}$ light/dark cycle with food and water ad libitum. Experiments were performed according to the principles of laboratory animal care (Law on animal experiments in Italy, DL 116/92). Rats were killed by decapitation and the brain areas of interest were rapidly dissected as previously described (Onali and Olianas, 2002, 2004b). The frontal lobes and the tissue samples from individual slices were homogenized in an ice-cold buffer containing $10 \mathrm{mM}$ HEPES-NaOH, $1 \mathrm{mM}$ EGTA, $1 \mathrm{mM} \mathrm{MgCl}_{2}$ (pH 7.40) using a Teflon-glass tissue grinder. The homogenate was centrifuged at $27000 \mathrm{~g}$ for $20 \mathrm{~min}$ at $4^{\circ} \mathrm{C}$. The pellet was resuspended in the same buffer at a protein concentration of $0.8-1.0 \mathrm{mg} / \mathrm{ml}$ and used immediately for adenylyl cyclase assays or stored at $-80^{\circ} \mathrm{C}$ for binding assays. For each experiment, a fresh tissue preparation was used.

\section{Assay of $\left[{ }^{35} \mathrm{~S}\right] \mathrm{GTP} \gamma \mathrm{S}$ Binding}

Cell and tissue membranes were diluted 10-fold in an ice-cold buffer containing $10 \mathrm{mM}$ HEPES/NaOH and $1 \mathrm{mM}$ EDTA ( $\mathrm{pH}$ 7.4), centrifuged at $32500 \mathrm{~g}$ for $30 \mathrm{~min}$ at $4{ }^{\circ} \mathrm{C}$ and resuspended in the same buffer containing $0.1 \%$ bovine serum albumin (BSA). The binding of $\left[{ }^{35} \mathrm{~S}\right] \mathrm{GTP} \gamma \mathrm{S}$ was assayed in a reaction mixture (final volume $100 \mu \mathrm{l})$ containing $25 \mathrm{mM} \mathrm{HEPES} / \mathrm{NaOH}(\mathrm{pH} 7.4)$, $10 \mathrm{mM} \mathrm{MgCl}_{2}, 1 \mathrm{mM}$ EDTA, $150 \mathrm{mM} \mathrm{KCl}, 10$ kallikrein inhibitor units (KIU) of aprotinin, $10 \mu \mathrm{M}$ leupeptin, $10 \mu \mathrm{M}$ bestatin, $1.0 \mathrm{nM}\left[{ }^{35} \mathrm{~S}\right] \mathrm{GTP} \gamma \mathrm{S}$. GDP was added at the concentration of $5 \mu \mathrm{M}$ for $\mathrm{CHO} / \mathrm{NOP}, 10 \mu \mathrm{M}$ for $\mathrm{CHO} /$ MOR-1, $30 \mu \mathrm{M}$ for $\mathrm{CHO} / \mathrm{KOR}$ and $\mathrm{CHO} / \mathrm{DOR}$, and $50 \mu \mathrm{M}$ for rat brain membranes. Membranes $(2-4 \mu \mathrm{g}$ of protein) were preincubated for $20 \mathrm{~min}$ at $30^{\circ} \mathrm{C}$ with the test compounds. For each compound, control samples received an equal volume $(10 \mu \mathrm{l})$ of vehicle to determine the basal values. The reaction was started by the addition of $\left[{ }^{35} \mathrm{~S}\right] \mathrm{GTP} \gamma \mathrm{S}$ and continued for $40 \mathrm{~min}$ at $30^{\circ} \mathrm{C}$. The incubation was terminated by the addition of $5 \mathrm{ml}$ of icecold buffer containing $10 \mathrm{mM}$ HEPES/NaOH (pH 7.4) and $1.0 \mathrm{mM} \mathrm{MgCl}_{2}$, immediately followed by rapid filtration on glass fiber filters (Whatman GF/C) presoaked in the same buffer. The filters were washed twice with $5 \mathrm{ml}$ of buffer and the radioactivity trapped was determined by liquid scintillation spectrometry. Nonspecific binding was determined in the presence of $50 \mu \mathrm{M}$ GTP $\gamma \mathrm{S}$. Assays were performed in duplicate.

\section{Assay of $\left[{ }^{3} \mathrm{H}\right]$ Cyclic AMP Accumulation}

$\mathrm{CHO}$ and NG108-15 cells grown in 36-mm plastic dishes were incubated in Ham's F-12 and DMEM, respectively, containing $10 \mu \mathrm{Ci} / \mathrm{ml}$ of $\left[{ }^{3} \mathrm{H}\right]$ adenine for $1 \mathrm{~h}$ at $37^{\circ} \mathrm{C}$ in an incubator. Thereafter, the medium was removed, and the cells were incubated in an oxygenated Krebs-HEPES uffer containing $1 \mathrm{mM}$ 3-isobutyl-1-methylxanthine (IBMX) for $10 \mathrm{~min}$ at $37^{\circ} \mathrm{C}$. Forskolin (FSK) $(10 \mu \mathrm{M})$ and the various test compounds were then added and the incubation was continued for $10 \mathrm{~min}$. Control samples were incubated in the presence of an equal volume of vehicle. The incubation was stopped by the aspiration of the medium and the addition of an ice-cold solution containing $6 \%(\mathrm{w} / \mathrm{v})$ perchloric acid and $0.1 \mathrm{mM}\left[{ }^{14} \mathrm{C}\right]$ cyclic AMP ( 4000 c.p.m.). After $30 \mathrm{~min}$ at ice-bath temperature, the solution was neutralized by the addition of ice-cold $0.6 \mathrm{M}$ $\mathrm{KOH}$ and left on ice for additional $30 \mathrm{~min}$. Following centrifugation at $20000 \mathrm{~g}$ for $5 \mathrm{~min}$, the supernatant was collected and $\left[{ }^{3} \mathrm{H}\right]$ cyclic AMP was isolated by sequential chromatography on Dowex and alumina columns. The recovery of $\left[{ }^{3} \mathrm{H}\right]$ cyclic AMP from each sample was corrected on the basis of the recovery of $\left[{ }^{14} \mathrm{C}\right]$ cyclic AMP.

\section{Assay of Adenylyl Cyclase}

The adenylyl cyclase activities of dorsal striatum, nucleus accumbens, and frontal cortex were assayed in a reaction mixture (final volume $100 \mu \mathrm{l}$ ) containing $50 \mathrm{mM}$ HEPES/ $\mathrm{NaOH}$ (pH 7.4), $2.3 \mathrm{mM} \mathrm{MgCl}_{2}, 0.3 \mathrm{mM}$ EGTA, $0.05 \mathrm{mM}$ $\left[\alpha-{ }^{32} \mathrm{P}\right]$ ATP $\quad\left(150\right.$ c.p.m./pmol), $0.5 \mathrm{mM}\left[{ }^{3} \mathrm{H}\right]$ cyclic AMP (80 c.p.m./nmol), $1 \mathrm{mM}$ IBMX, $5 \mathrm{mM}$ phosphocreatine, $50 \mathrm{U} / \mathrm{ml}$ of creatine phosphokinase, $100 \mu \mathrm{M}$ GTP, $50 \mu \mathrm{g}$ of BSA, $10 \mu \mathrm{g}$ of bacitracin, and $10 \mathrm{KIU}$ of aprotinin. FSK was present at the final concentration of $10 \mu \mathrm{M}$. The reaction was started by the addition of the tissue preparation (30$35 \mu \mathrm{g}$ of protein) and was carried out at $25^{\circ} \mathrm{C}$ for $20 \mathrm{~min}$. When the basal enzyme activity of the granule cell layer of rat olfactory bulb was measured, the $\left[\alpha_{-}{ }^{32} \mathrm{P}\right]$ ATP concentration was $0.2 \mathrm{mM}$, FSK was omitted and the incubation was carried out at $30^{\circ} \mathrm{C}$ for $10 \mathrm{~min}$. The reaction was stopped by the addition of $200 \mu \mathrm{l}$ of a solution containing $2 \%(\mathrm{w} / \mathrm{v})$ sodium dodecyl sulfate (SDS), $45 \mathrm{mM}$ ATP, $1.3 \mathrm{mM}$ cyclic AMP (pH 7.5). Cyclic AMP was isolated by sequential chromatography on Dowex and alumina columns. The recovery of $\left[{ }^{32} \mathrm{P}\right]$ cyclic AMP from each sample was calculated on the basis of the recovery of $\left[{ }^{3} \mathrm{H}\right]$ cyclic AMP. Assays were carried out in duplicate.

\section{Receptor Binding Assays}

Radioligands used for receptor binding assays were $\left[{ }^{3} \mathrm{H}\right] \mathrm{NTI}$ in the experiments using $\mathrm{CHO} / \mathrm{DOR}$ cell membranes and $\left[{ }^{3} \mathrm{H}\right]$ diprenorphine in the experiments using CHO/MOR-1 and $\mathrm{CHO} / \mathrm{KOR}$ cell membranes. For $\left[{ }^{3} \mathrm{H}\right] \mathrm{NTI}$ competition binding assays, CHO/DOR cell membranes $(40-50 \mu \mathrm{g}$ of protein) were incubated at $30^{\circ} \mathrm{C}$ for $60 \mathrm{~min}$ in a medium containing $25 \mathrm{mM} \mathrm{HEPES} / \mathrm{NaOH}$ (pH 7.4), $10 \mathrm{mM} \mathrm{MgCl}_{2}$, $1 \mathrm{mM}$ EDTA, $150 \mathrm{mM} \mathrm{KCl}, 10 \mathrm{KIU}$ of aprotinin, $10 \mu \mathrm{M}$ leupeptin, $10 \mu \mathrm{M}$ bestatin, and the indicated concentrations of the test compounds. When the effects of guanine nucleotides were examined, competition binding assays 
were performed in the presence of $1.0 \mathrm{nM} \mathrm{GTP} \gamma \mathrm{S}$ and $30 \mu \mathrm{M}$ GDP to keep the conditions similar to those used in the $\left[{ }^{35} \mathrm{~S}\right] \mathrm{GTP} \gamma \mathrm{S}$ binding assays. The concentration of $\left[{ }^{3} \mathrm{H}\right] \mathrm{NTI}$ was $0.16 \mathrm{nM}$ and the assay volume was $2.0 \mathrm{ml}$. Competition binding experiments in CHO/MOR-1 (70-80 $\mu$ g of protein) or $\mathrm{CHO} / \mathrm{KOR}(15-20 \mu \mathrm{g}$ of protein) cell membranes were performed using $0.2 \mathrm{nM}\left[{ }^{3} \mathrm{H}\right]$ diprenorphine under the experimental conditions indicated above with the exception that the assay volume was $1.0 \mathrm{ml}$. For saturation binding assays, membrane preparations of $\mathrm{CHO} / \mathrm{DOR}(30 \mu \mathrm{g}$ of protein), CHO/MOR-1 (60 $\mu \mathrm{g}$ of protein) and $\mathrm{CHO} / \mathrm{KOR}$ $\left(15 \mu \mathrm{g}\right.$ of protein) were incubated at $30^{\circ} \mathrm{C}$ for $120 \mathrm{~min}$ in the presence of either $\left[{ }^{3} \mathrm{H}\right] \mathrm{NTI}$ (from $8 \mathrm{pM}$ to $1.5 \mathrm{nM}$ ) or $\left[{ }^{3} \mathrm{H}\right]$ diprenorphine (from $20 \mathrm{pM}$ to $3.0 \mathrm{nM}$ ). Nonspecific binding was determined in the presence of $10 \mu \mathrm{M}$ naloxone. For each compound, control samples received an equal volume of vehicle. Reactions were terminated by the addition of $5 \mathrm{ml}$ of ice-cold buffer containing $10 \mathrm{mM}$ $\mathrm{HEPES} / \mathrm{NaOH}$ ( $\mathrm{pH}$ 7.4) and $1 \mathrm{mM} \mathrm{MgCl}_{2}$ immediately followed by rapid filtration through glass fiber filters (Whatman GF/C) presoaked with $0.1 \%$ polyethylenimine. The filters were washed twice with $5 \mathrm{ml}$ of buffer and the radioactivity trapped was determined by liquid scintillation spectrometry. Assays were performed in triplicate.

\section{Indirect Immunofluorescence Analysis}

Cells were grown in tissue culture chamber slides (Nunc Lab-Tek II treated with CC2) and serum starved for $12 \mathrm{~h}$. Following the addition of fresh serum-free medium, the cells were treated with the test compounds and placed in the incubator for $20 \mathrm{~min}$ at $37^{\circ} \mathrm{C}$. Thereafter, the medium was removed and the cells were rapidly washed with PBS. Following fixation with $4 \%$ paraformaldehyde in PBS for 10 min, the cells were treated with $0.5 \%$ Triton X-100 in PBS for $7 \mathrm{~min}$, and blocked with $10 \%$ normal goat serum (NGS) in PBS for $20 \mathrm{~min}$. The cells were then washed and incubated with a rabbit anti phospho-ERK1/2 affinity purified antibody (1:1000 dilution in PBS containing $0.25 \%$ Triton X-100 and $1.5 \%$ NGS; Neuromics, Northfield, $\mathrm{MN}$ ) overnight at $4{ }^{\circ} \mathrm{C}$. After washing with PBS, the cells were incubated with fluorescein isothiocyanate (FITC)conjugated goat anti-rabbit IgG $(1 \mu \mathrm{g} / \mathrm{ml}$ in PBS containing 1.5\% NGS; Santa Cruz Biotechnology Inc., Santa Cruz, CA) for $45 \mathrm{~min}$ at room temperature. After a final washing step, the glass slides were covered with coverslips in Gel Mount aqueous mounting medium (Sigma). The cells were analyzed with a Olympus IX51 microscope and images were captured with a Olympus digital camera. Negative controls were incubated with FITC-conjugated secondary antibody only. The percent of immunolabeled cells was determined by examining at least four fields in each sample and calculated by counting the total number of cells present in each optic field, which ranged from 80 to 100. Cell counting was performed by an investigator unaware of the drug treatment protocol.

\section{Western Blot Analysis}

For the assay of ERK1/2 phosphorylation in cell extracts, serum-starved NG-108-15 cells grown in $36 \mathrm{~mm}$ Petri dishes were treated with the test compounds as indicated above and cell extracts were prepared by scraping the cells in icecold PBS containing $0.1 \%$ SDS, $1 \%$ Nonidet P-40, $0.5 \%$ sodium deoxycholate, $2 \mathrm{mM}$ EDTA, $2 \mathrm{mM}$ EGTA, $4 \mathrm{mM}$ sodium pyrophosphate, $2 \mathrm{mM}$ sodium orthovanadate, $10 \mathrm{mM}$ sodium fluoride, $0.1 \%$ phosphatase inhibitor cocktail 1 (Sigma), and a protease inhibitor cocktail $(100 \mathrm{KIU} / \mathrm{ml}$ of aprotinin, $10 \mu \mathrm{g} / \mathrm{ml}$ of leupeptin, $10 \mu \mathrm{g} / \mathrm{ml}$ of soybean trypsin inhibitor, $3 \mu \mathrm{M}$ pepstatin, and $1 \mathrm{mM}$ phenylmethylsulfonyl fluoride). The samples were sonicated for $5 \mathrm{~s}$ in ice-bath and aliquots of the cell extracts containing equal amount of cell proteins were mixed with a $5 \times$ solution of sample buffer (300 mM Tris- $\mathrm{HCl}, 10 \%$ SDS, 40\% glycerol, $10 \% \beta$-mercaptoethanol, and $0.008 \%$ bromophenol blue, $\mathrm{pH}$ 6.8 ), heated at $100^{\circ} \mathrm{C}$ for $5 \mathrm{~min}$, and subjected to SDSpolyacrilamide gel electrophoresis. The proteins were electrophoretically transferred onto polyvinylidene difluoride membranes (Immobilon-P, Millipore Corp.), according to the method of Towbin et al (1979). The efficiency of the transfer was controlled by staining the gel with Coomassie Brilliant Blue and by following the transfer of prestained protein standards (Santa Cruz Biotechnology Inc.). Nonspecific binding sites were blocked by incubation in $20 \mathrm{mM}$ Tris- $\mathrm{HCl}, 137 \mathrm{mM} \mathrm{NaCl}$, and $0.05 \%$ Tween-20 ( $\mathrm{pH}$ 7.6) (TBS-T buffer) containing 5\% BSA for $1 \mathrm{~h}$ at room temperature. After washing with TBS-T buffer, the membranes were incubated overnight at $4{ }^{\circ} \mathrm{C}$ with the antiphospho-ERK1/2 antibody (1:1000 in TBS-T containing $0.1 \%$ BSA). For assurance that equivalent amount of total ERK was loaded in each lane, the blots were incubated with an anti-ERK1 affinity purified antibody $(1: 1000)$ (Neuromics). The membranes were then washed with TBS-T and incubated with a horseradish peroxidase-conjugated second antibody (1:10000 Santa Cruz Biotechnology Inc.) for $45 \mathrm{~min}$ at room temperature. Immunoreactive bands were detected by using an enhanced chemiluminescence system (ECL Plus) and ECL Hyperfilm (Amersham). In each experiment, the size of the immunoreactive bands was determined by using molecular weight standards detected with a specific antibody suitable for the ECL system (Santa Cruz Biotechnology Inc.). Band densities were determined by densitometric analysis using the NIH ImageJ software. In each experiment, the optical density of the phospho-ERK1/2 bands was normalized to the density of the corresponding ERK1 internal control.

Protein content was determined by the method of Bradford (1976) using BSA as a standard.

\section{Statistical Analysis}

Results are reported as mean \pm standard error of the mean (SEM). Data from concentration-response curves were analyzed by the program Graph Pad Prism (San Diego, CA, USA.), which yielded agonist concentration producing half-maximal effect ( $\left(\mathrm{EC}_{50}\right.$ values) and maximal effects $\left(E_{\max }\right)$. For statistical analysis, the $\mathrm{EC}_{50}$ values were converted to the logarithmic form $\left(\mathrm{pEC}_{50}=\right.$ negative logarithm of $\mathrm{EC}_{50}$ ) as they are log-normally distributed (Fleming et al, 1972). The percent of maximal effect (\% $\left.E_{\max }\right)$ by the drugs at the $\delta$-opiod receptor was calculated as net maximal effect of the agonist/net maximal effect elicited by DPDPE $\times 100$. Saturation binding data were analyzed by the LIGAND program (Munson and Rodbard, 1980). 
Antagonist potencies in functional assays and radioligand competition curves were analyzed by nonlinear regression analysis and the antagonist inhibitory constant $\left(K_{\mathrm{i}}\right)$ was calculated according to the Cheng-Prusoff equation (Cheng and Prusoff, 1973). $K_{\mathrm{i}}$ values were converted to the logarithmic form $\left(\mathrm{p} K_{\mathrm{i}}\right)$. The $K_{\mathrm{i}} / \mathrm{EC}_{50}$ ratio was determined to be significantly different from one when the corresponding $\mathrm{p} K_{\mathrm{i}}$ and $\mathrm{pEC}_{50}$ values were significantly different. When the difference was not significant, the ratio was considered equal to 1 . The efficacy of the opioid receptor ligands in stimulating $\left[{ }^{35} \mathrm{~S}\right] \mathrm{GTP} \gamma \mathrm{S}$ binding was calculated according to the method described by Ehlert (1985) and Quock et al (1999), in which efficacy $=\left(E_{\text {max- } \mathrm{A}} / E_{\text {max-B } \mathrm{B}}\right) \times\left(K_{\mathrm{i}} / \mathrm{EC}_{50}+1\right) \times 0.5$, where $E_{\text {max-A }}$ is the maximal effect elicited by the test compound, $E_{\max -\mathrm{B}}$ is the maximal effect elicited by DPDPE, respectively, $K_{\mathrm{i}}$ is the inhibition constant of the compound obtained from competition binding experiments in the presence of guanine nucleotides, and $\mathrm{EC}_{50}$ is the concentration of the compound producing half-maximal effect. Statistical analysis was performed by either Student's $t$-test when comparing two groups and one-way ANOVA followed by Dunnett post hoc test when comparing more than one group.

\section{RESULTS}

\section{Effects in CHO Cells Expressing the Cloned Human Opioid Receptors}

As shown in Figure 1a, in CHO/DOR cell membranes NDMC elicited a concentration-dependent stimulation of
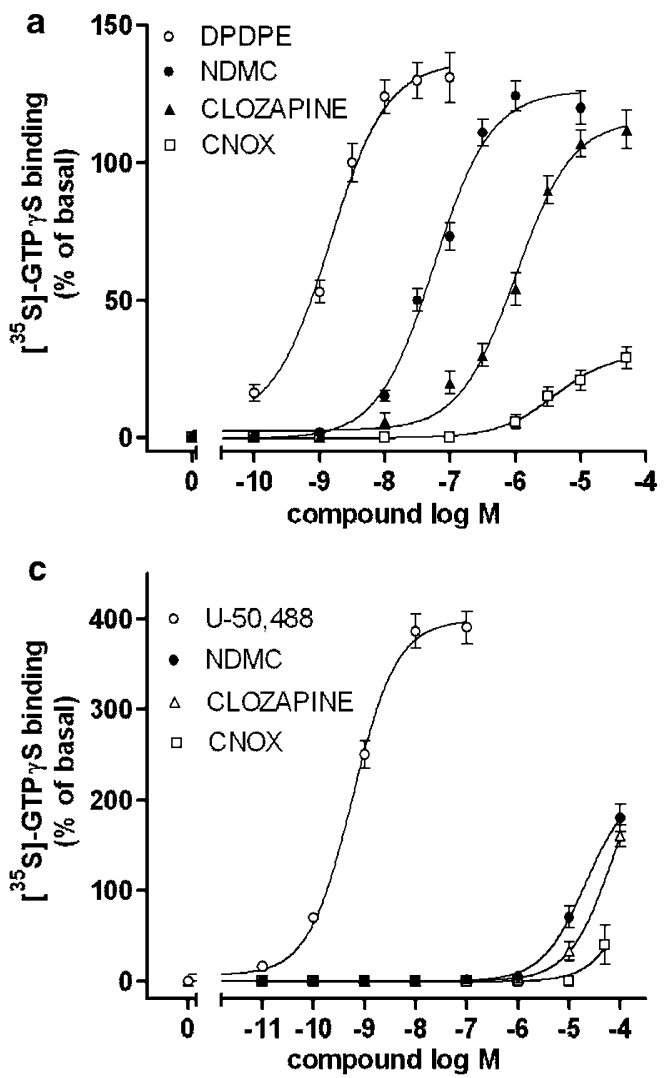

$\left[{ }^{35} \mathrm{~S}\right] \mathrm{GTP} \gamma \mathrm{S}$ binding with a $\mathrm{pEC}_{50}$ of $7.24 \pm 0.01$ and a maximal effect corresponding to $124 \pm 5 \%$ increase of basal activity. This stimulation was about $95 \%$ of that displayed by the full $\delta$-opioid receptor agonist DPDPE (Table 1 ). Clozapine was less effective than NDMC and displayed a much lower potency $\left(\mathrm{pEC}_{50}=5.90 \pm 0.04\right)$. On the other hand, CNOX was a weak agonist, eliciting a small stimulatory effect ( $30 \pm 6 \%$ increase) only at concentrations above $1 \mu \mathrm{M}\left(\mathrm{pEC}_{50}=5.41 \pm 0.02\right)$. The $\delta$-opioid receptor antagonist TIPP completely antagonized the stimulatory effects elicited by NDMC and clozapine with $\mathrm{p} K_{\mathrm{i}}$ values of $9.43 \pm 0.05$ and $9.37 \pm 0.06$, respectively, which were similar to that displayed in blocking the DPDPE response $\left(\mathrm{p} K_{\mathrm{i}}=9.63 \pm 0.03\right)$ (Figure 2).

NDMC, clozapine, and CNOX failed to show agonist-like activity in CHO/MOR-1 cell membranes under conditions where the full $\mu$-opioid receptor agonist DAMGO stimulated $\left[{ }^{35}\right.$ S $]$ GTP $\gamma$ S binding by $200 \%$ (Figure 1b). Similarly, in CHO/ KOR cell membranes, NDMC and clozapine did not change $\left[{ }^{35} \mathrm{~S}\right] \mathrm{GTP} \gamma \mathrm{S}$ binding at concentrations up to $1 \mu \mathrm{M}$ and CNOX up to $10 \mu \mathrm{M}$ (Figure 1c). At higher concentrations, NDMC and clozapine caused a stimulatory effect, which did not reach saturation at $100 \mu \mathrm{M}$, the highest concentration tested. For comparison, in these cells the $\kappa$-opioid receptor agonist (-)-U-50,488 stimulated $\left[{ }^{35} \mathrm{~S}\right] \mathrm{GTP} \gamma \mathrm{S}$ binding by four-fold with a $\mathrm{pEC}_{50}$ of 9.24. Finally, in $\mathrm{CHO} / \mathrm{NOP}$ cell membranes NDMC and the other two compounds were without effect up to $30 \mu \mathrm{M}$, whereas the NOP receptor agonist N/OFQ maximally stimulated $\left[{ }^{35} \mathrm{~S}\right] \mathrm{GTP} \gamma \mathrm{S}$ binding by $130 \%$ (Figure 1d).
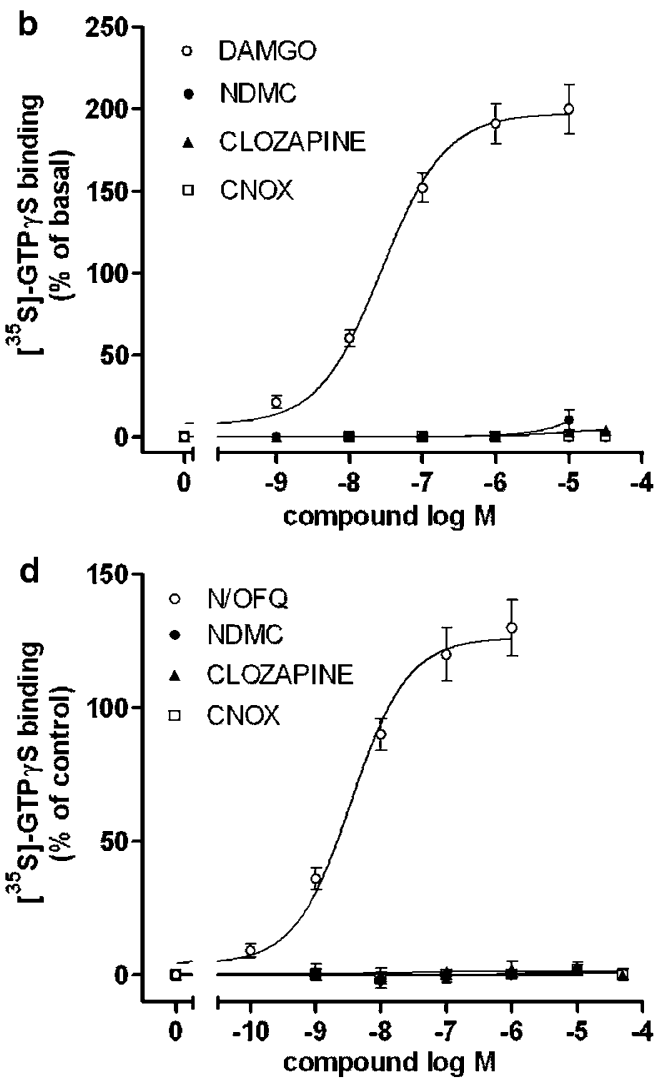

Figure I Effects of NDMC, clozapine, CNOX, and reference opioid agonists on $\left[{ }^{35} \mathrm{~S}\right] \mathrm{GTP} \gamma \mathrm{S}$ binding in membranes of $\mathrm{CHO} / \mathrm{DOR}$ (a), CHO/MOR-I (b), $\mathrm{CHO} / \mathrm{KOR}$ (c), and $\mathrm{CHO} / \mathrm{NOP}$ (d) cells. Values are reported as percent of basal activity and are the mean \pm SEM of three to six experiments. 
Table I Potencies and Relative Efficacies of N-Desmethylclozapine, Clozapine, and Clozapine N-Oxide in Stimulating $\left.{ }^{35} \mathrm{~S}\right] \mathrm{GTP} \gamma \mathrm{S}$ Binding at the Cloned Human $\delta$-Opioid Receptor

\begin{tabular}{|c|c|c|c|c|c|}
\hline Agonist & $\% E_{\max }{ }^{a}$ & $\mathrm{EC}_{50}(\mathrm{nM})(n)$ & $K_{\mathrm{i}}^{\mathrm{b}}(\mathrm{nM})(n)$ & $K_{\mathrm{i}} / E C_{50}$ & Efficacy ${ }^{c}$ \\
\hline DPDPE & 100 & $1.5 \pm 0.2(5)$ & $84.4 \pm 7.2(4)$ & 56.3 & 28.6 \\
\hline N-desmethylclozapine & $95 \pm 3$ & $57.5 \pm 1.5(6)$ & $2636 \pm 140(4)$ & 45.8 & 23.4 \\
\hline Clozapine & $82 \pm 4$ & $\mid 250 \pm 110$ (4) & $27900 \pm 2400$ & 22.3 & 9.50 \\
\hline Clozapine $\mathrm{N}$-oxide & $23 \pm 5$ & $3840 \pm 225$ & $3080 \pm 160(3)$ & $0.80^{d}$ & 0.23 \\
\hline
\end{tabular}

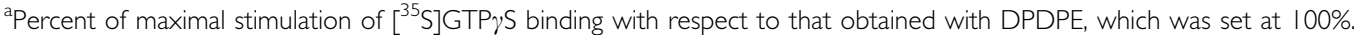

betermined in competition binding experiments in the presence of $30 \mu \mathrm{M}$ GDP and I nM GTP $\gamma \mathrm{S}$

'Determined according to the equation described in Statistical analysis section.

dNot significantly different from $1 ; n=$ number of experiments.

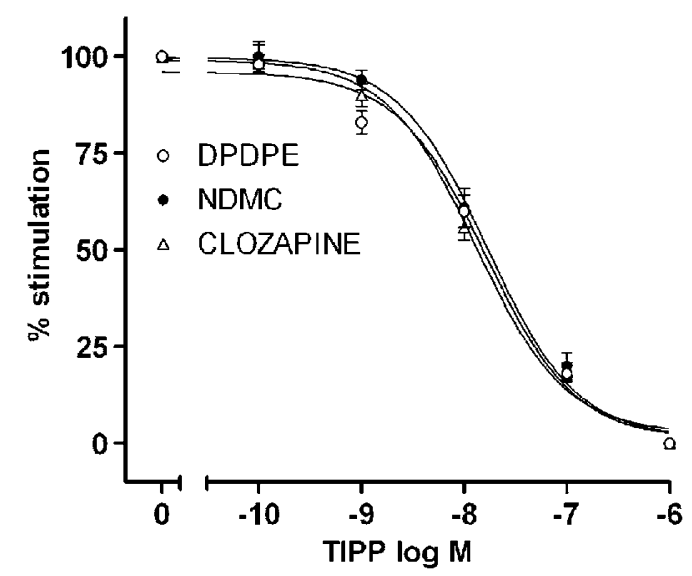

Figure 2 Antagonism of DPDPE-, NDMC- and clozapine-stimulated $\left[{ }^{35} \mathrm{~S}\right] \mathrm{GTP} \gamma \mathrm{S}$ binding by TIPP in CHO/DOR cell membranes. Values indicate the percent of the stimulatory effect of either $0.1 \mu \mathrm{M}$ DPDPE, $3 \mu \mathrm{M}$ NDMC, or $30 \mu \mathrm{M}$ clozapine at each concentration of TIPP and are the mean \pm SEM of three experiments.

In intact $\mathrm{CHO} / \mathrm{DOR}$ cells, NDMC inhibited FSK-stimulated cyclic AMP accumulation with a $\mathrm{pEC}_{50}$ value of $6.40 \pm 0.04$ and a maximal effect corresponding to $78 \pm 5 \%$ decrease of control activity $(n=3)$ (results not shown). This effect was equal to $96 \pm 5 \%$ of the maximal inhibitory response elicited by DPDPE. Clozapine was significantly less potent $\left(\mathrm{pEC}_{50}=5.05 \pm 0.06, p<0.01\right)$ and less efficacious (67 $\pm 3 \%$ inhibition), whereas CNOX showed little agonist activity, maximally inhibiting cyclic AMP accumulation by $16 \pm 4 \%$ with a $\mathrm{pEC}_{50}$ of $5.50 \pm 0.10 \quad(n=3)$ (results not shown). In CHO/MOR-1 and CHO/KOR cells, NDMC, clozapine, and CNOX failed to significantly affect FSKstimulated cyclic AMP accumulation at concentrations up to $30 \mu \mathrm{M}(n=3)$ (results not shown).

\section{Determination of Ligand-Binding Affinities}

Increasing concentrations of NDMC inhibited $\left[{ }^{3} \mathrm{H}\right] \mathrm{NTI}$ binding to $\mathrm{CHO} / \mathrm{DOR}$ membranes with a competition curve that was best fit by a two-site model, indicating the occurrence of a high- $\left(52.8 \pm 4 \%, \mathrm{p} K_{\mathrm{i}}=7.42 \pm 0.03\right)$ and a low-affinity component $\left(\mathrm{p} K_{\mathrm{i}}=5.47 \pm 0.05\right)$ (Figure $\left.3 \mathrm{a}\right)$. In the presence of guanine nucleotides $(30 \mu \mathrm{M}$ GDP and $1 \mathrm{nM}$ GTP $\gamma$ S), the NDMC competition curve was monophasic and shifted to the right, with a $\mathrm{p} K_{\mathrm{i}}$ of $5.57 \pm 0.02$. Clozapine inhibited $\left[{ }^{3} \mathrm{H}\right]$ NTI binding with a pattern similar to that of NDMC (Figure $3 \mathrm{~b}$ ), but with lower $\mathrm{p} K_{\mathrm{i}}$ values both in the absence (high-affinity component $50 \pm 3 \%, \mathrm{p} K_{\mathrm{i}}=5.84 \pm$ 0.03 ; low-affinity component $\left.\mathrm{p} K_{\mathrm{i}}=4.46 \pm 0.05\right)$ and in the presence of guanine nucleotides (single component with $\left.\mathrm{p} K_{\mathrm{i}}=4.55 \pm 0.04\right)$. Conversely, CNOX generated monophasic inhibition curves with similar $\mathrm{p} K_{\mathrm{i}}$ values in the absence $(5.59 \pm 0.05)$ and in the presence of guanine nucleotides $(5.51 \pm 0.03)$ (Figure $3 c$ ).

In competition binding experiments performed using $\mathrm{CHO} / \mathrm{KOR}$ cell membranes and in the absence of added guanine nucleotides, NDMC inhibited the binding of $\left[{ }^{3} \mathrm{H}\right]$ diprenorphine $(0.2 \mathrm{nM})$ with a steep monophasic competition curve and a $\mathrm{p} K_{\mathrm{i}}$ of $4.76 \pm 0.04$, whereas clozapine caused less than $50 \%$ inhibition at $100 \mu \mathrm{M}$, the highest concentration tested $(n=3)$ (results not shown). Finally, in CHO/MOR-1 cell membranes, NDMC, clozapine and CNOX failed to affect the binding of $0.2 \mathrm{nM}\left[{ }^{3} \mathrm{H}\right]$ diprenorphine at concentrations up to $50 \mu \mathrm{M}(n=3)$ (results not shown).

\section{Determination of $\boldsymbol{\delta}$-Opioid Receptor Agonist Efficacy}

The efficacies of NDMC and the other two related compounds in stimulating $\left[{ }^{35} \mathrm{~S}\right] \mathrm{GTP} \gamma \mathrm{S}$ binding to $\mathrm{CHO} /$ DOR membranes were determined according to the method of Ehlert (1985), which takes into consideration both the magnitude of the agonist effect and the extent of receptor occupancy at which half-maximal effect occurred $\left(K_{\mathrm{i}} / \mathrm{EC}_{50}\right.$ ratio). As shown in Table 1, NDMC exhibited a high $K_{\mathrm{i}} / \mathrm{EC}_{50}$ ratio and an efficacy value equal to $82 \%$ of that displayed by DPDPE, whereas clozapine and CNOX had lower receptor reserve and efficacy values corresponding to 33 and $0.8 \%$ of that of the full agonist, respectively.

\section{Effects in NG 108-15 Cells}

In NG108-15 cells naturally expressing the $\delta$-opioid receptors, NDMC inhibited FSK-stimulated cyclic AMP accumulation almost as effectively as DPDPE $(65 \pm 5 \%$ reduction of control activity) and with a $\mathrm{pEC}_{50}$ value of $5.80 \pm 0.05$ (Figure 4a). Clozapine was less potent $\left(\mathrm{pEC}_{50}=5.01 \pm 0.06\right)$ and less efficacious $(43 \pm 4 \%$ inhibition of control activity) than the $\mathrm{N}$-demethylated metabolite, whereas CNOX was inactive. NTI antagonized the 

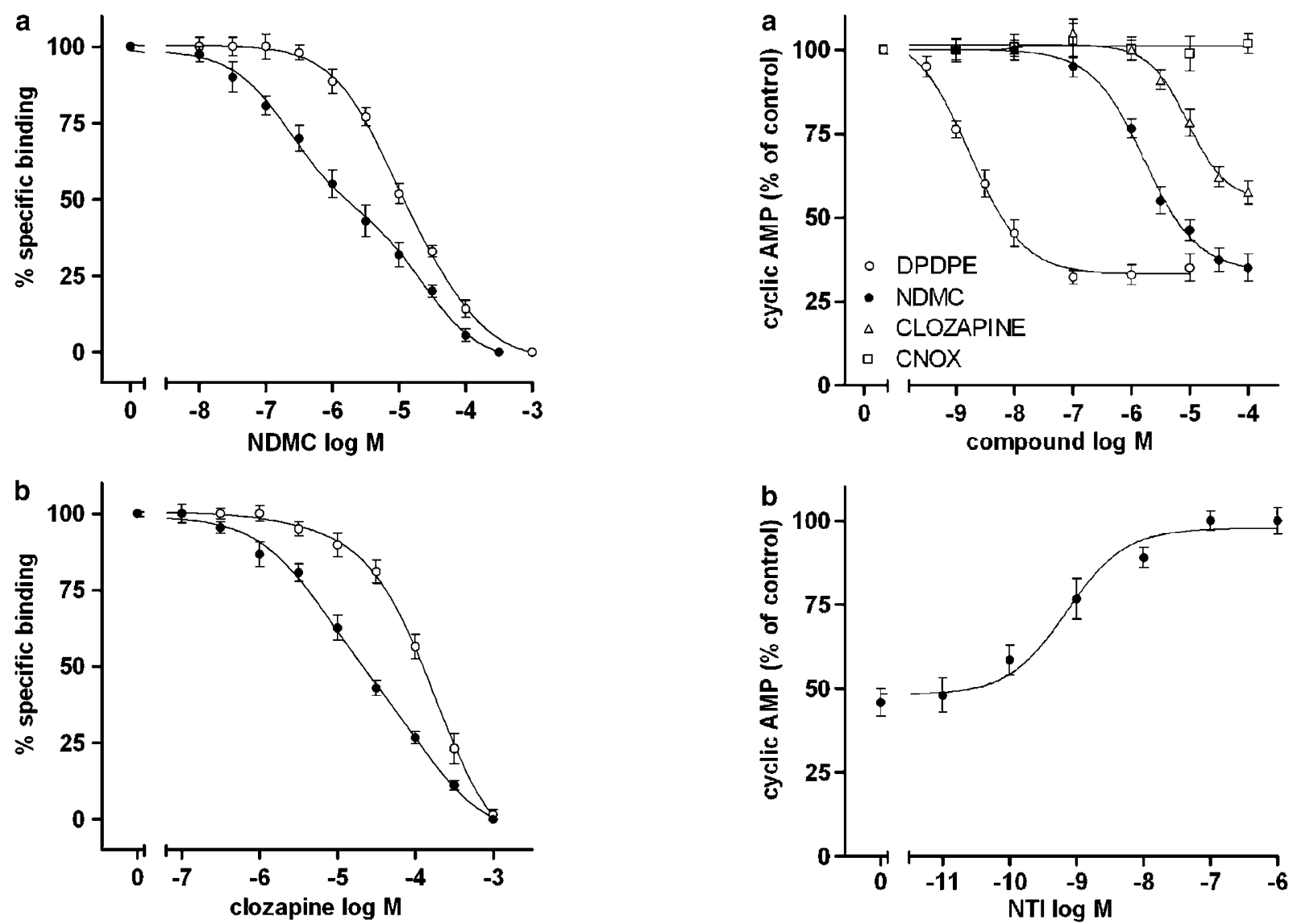

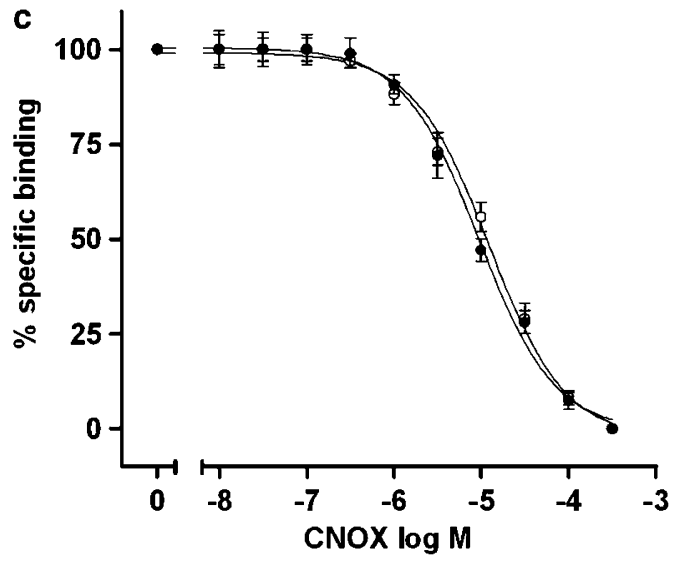

Figure 3 Competition for $\left.{ }^{3} \mathrm{H}\right] \mathrm{NTI}$ binding to $\mathrm{CHO} / \mathrm{DOR}$ cell membranes by NDMC, clozapine, and CNOX in the absence (closed symbols) and in the presence (open symbols) of $30 \mu \mathrm{M}$ GDP plus I nM GTP $\gamma \mathrm{S}$. Values indicate the percent of specific binding at each competitor concentration and are the mean \pm SEM of three to four determinations.

NDMC inhibitory effect with a $\mathrm{p} K_{\mathrm{i}}$ value of $10.14 \pm 0.01$, which was consistent with its $\delta$-opioid receptor affinity (Figure 4b).

Immunocytochemical analysis showed that exposure of NG108-15 cells to NDMC $(10 \mu \mathrm{M})$ for 20 min caused a marked stimulation of ERK1/2 phosphorylation, and this effect was antagonized by the concomitant addition of $1 \mu \mathrm{M}$ NTI (Figure 5a). The percent values of immunolabeled cells were: control $24 \pm 3$, NDMC $60 \pm 5(p<0.05 v s$ control), NTI $28 \pm 5$ ( $p>0.05 v s$ control), and NTI + NDMC $32 \pm 7$

\section{Effects in Rat Brain Membranes}

In membranes of dorsal striatum, nucleus accumbens, and frontal cortex NDMC stimulated $\left[{ }^{35} \mathrm{~S}\right] \mathrm{GTP} \gamma \mathrm{S}$ binding by $63.0 \pm 4.0,60 \pm 3.0$, and $72.0 \pm 6.0 \%(p<0.001)$, respectively, with $\mathrm{pEC}_{50}$ values of $6.18 \pm 0.07,6.15 \pm 0.08$, and $6.07 \pm 0.05$, respectively (Figure $6 \mathrm{a}-\mathrm{c}$ ). In the same brain regions, NDMC inhibited FSK-stimulated adenylyl cyclase activity by $31 \pm 4,24 \pm 4$, and $21 \pm 3 \%(p<0.01)$ with $\mathrm{pEC}_{50}$ values of $5.85 \pm 0.06,5.73 \pm 0.03$, and $5.76 \pm 0.02$, respectively. Conversely, in membranes of rat thalamus, which expresses a low level of $\delta$-opioid receptors and a high density of $\mu$ opioid receptors (Mansour et al, 1995), $\left[{ }^{35} \mathrm{~S}\right] \mathrm{GTP} \gamma \mathrm{S}$ binding was weakly affected by NDMC $(<10 \pm 3 \%$ increase at $10 \mu \mathrm{M}, n=3)$, but it was markedly stimulated by DAMGO ( $160 \pm 8 \%$ increase at $1 \mu \mathrm{M}, n=3$ ) (results not shown). In membranes of the granule cell layer of the main olfactory 

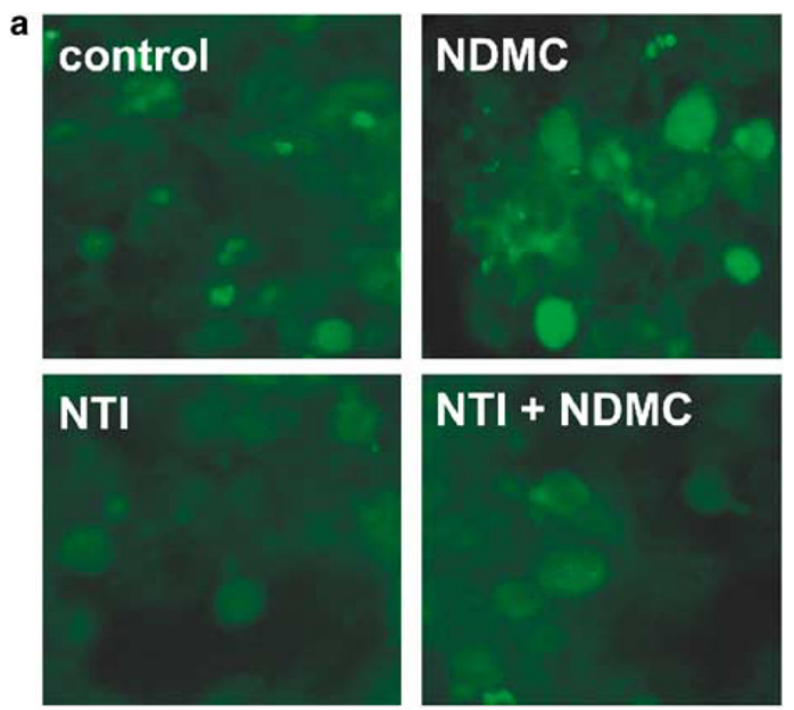

b

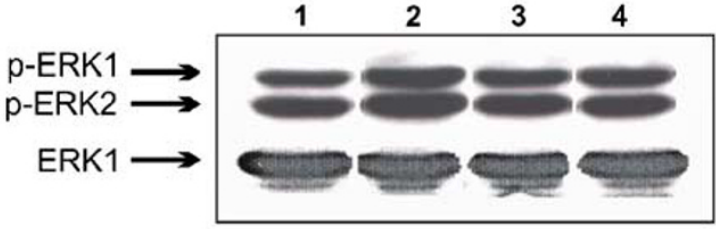

c

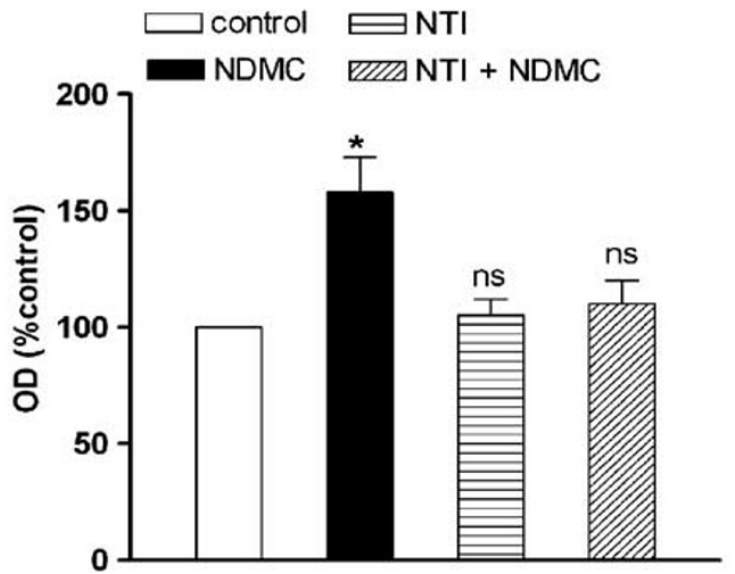

Figure 5 Stimulation of ERKI/2 phosphorylation by NDMC in NG I0815 cells. (a) Immunofluorescence analysis of phospho-ERKI/2 immunoreactivity. Cells were serum-starved for $12 \mathrm{~h}$ and then treated with either vehicle (control), I $0 \mu \mathrm{M}$ NDMC, I $\mu \mathrm{M} N \mathrm{NTI}$, and NTI + NDMC for $20 \mathrm{~min}$, fixed and immunostained with anti-phospho-ERKI/2 antibody followed by FITC-conjugated secondary antibody. Results are representative of three similar experiments. (b) Western blot analysis of phospho-ERKI/2 immunoreactivity. Serum-starved cells were treated for $20 \mathrm{~min}$ with vehicle (lane I), I0 $\mu \mathrm{M}$ NDMC (lane 2), I $\mu \mathrm{M}$ NTI (lane 3), and NTI + NDMC (lane 4). Thereafter, cell extracts were prepared and equal amounts of proteins $(30 \mu \mathrm{g})$ were loaded in each lane. Samples were subjected to immunoblotting with either anti-phospho-ERKI/2 antibody (top) or antiERKI antibody (bottom). Results are representative of three similar experiments. (c) Densitometric analysis of immunoreactive phospho-ERKI/ 2 bands. The optical density of the phospho-ERKI/2 bands for each drug treatment was normalized to the density of the corresponding ERKI band and is reported as percent of control. Values are the mean \pm SEM of three experiments. ${ }^{*} p<0.05$ vs control, NS $p>0.05$ vs control by one-way ANOVA followed by Dunnett's test.

bulb, where previous studies have demonstrated the occurrence of a positive coupling of $\delta$-opioid receptors to adenylyl cyclase (Onali and Olianas, 2004b), NDMC stimulated both $\left[{ }^{35} \mathrm{~S}\right] \mathrm{GTP} \gamma \mathrm{S}$ binding and cyclic AMP formation by $170 \pm 8$ and $75 \pm 4 \%(p<0.001)$, respectively, with $\mathrm{pEC}_{50}$ values of $5.88 \pm 0.04$ and $5.87 \pm 0.05$, respectively (Figure 6d). For comparison, DPDPE maximally stimulated $\left[{ }^{35} \mathrm{~S}\right] \mathrm{GTP} \gamma \mathrm{S}$ binding by $74 \pm 4,80 \pm 5,83 \pm 3$, and $182 \pm 9 \%$ in membranes of dorsal striatum, nucleus accumbens, frontal cortex, and olfactory bulb granule cell layer, respectively $(n=3)$ (results not shown). Unlike NDMC, clozapine caused little changes in both functional assays, whereas CNOX was completely inactive. As shown in Figure 7, in each brain area NTI antagonized the NDMC stimulations of $\left[{ }^{35} \mathrm{~S}\right] \mathrm{GTP} \gamma \mathrm{S}$ binding by $80-90 \%$ with $\mathrm{p} K_{\mathrm{i}}$ values ranging from 10.53 to 10.15 . Conversely, the $\kappa$-opioid receptor antagonist nor-binaltorphimine (nor-BNI) showed $\mathrm{p} K_{\mathrm{i}}$ values of $8.19-8.50$, which were about 100 -fold lower than the affinity for the $\kappa$-opioid receptor $\left(\mathrm{p} K_{\mathrm{i}}=10.20\right)$. The $\mu$-opioid receptor antagonist CTAP failed to counteract the agonist effects of NDMC in each brain region.

\section{DISCUSSION}

In the present study, we show that the clozapine major metabolite NDMC behaves as selective and efficacious agonist at the $\delta$-opioid receptor. In $\mathrm{CHO} / \mathrm{DOR}$ cells, the drug exhibited full agonist activity in both $\left[{ }^{35} S\right] G T P \gamma S$ binding and cyclic AMP accumulation assays, and the activity was blocked by TIPP with a potency similar to that displayed in antagonizing DPDPE, demonstrating the mediation by a common recognition site. The functional selectivity for the $\delta$-opioid receptor is indicated by the lack of agonist effects in both CHO/MOR-1 and CHO/NOP cells, and by the about 300- to 1000-fold higher threshold concentration for the activation of the $\kappa$-opioid receptor in $\mathrm{CHO} / \mathrm{KOR}$ cells. Moreover, in radioligand binding assays, NDMC showed an affinity for the $\delta$-opioid receptor, which was about 60 -fold higher than that for the $\kappa$-opioid receptor and a very low affinity for the $\mu$-opioid receptor. These results are in agreement with the $K_{\mathrm{i}}$ Database of the NIMH psychoactive drug screening program (http://pdsp.cwru. edu/pdsp.php), which reports an NDMC $K_{\mathrm{i}}$ value of $127.9 \mathrm{nM}$ for the $\delta$-opioid receptors and $K_{\mathrm{i}}$ values higher than $10 \mu \mathrm{M}$ for both $\mu$ - and $\kappa$-opioid receptors. As expected for an agonist acting at a $G$ protein-coupled receptor, in CHO/DOR cell membranes NDMC inhibited [ $\left.{ }^{3} \mathrm{H}\right] \mathrm{NTI}$ binding with shallow competition curves, indicating the presence of a high- and a low-affinity binding site. The addition of guanine nucleotides markedly reduced the fraction of the high-affinity component and shifted the competition curve to describe a single low-affinity binding site. This allosteric regulation by guanine nucleotides has been documented for agonists, but not for antagonists, at the $\delta$-opioid receptor (Werling et al, 1988). When the efficacy was determined, we found that NDMC exhibited a relatively high $K_{\mathrm{i}} / \mathrm{EC}_{50}$ ratio and an efficacy value slightly lower than that of the full agonist DPDPE, indicating that the drug activates $\delta$-opioid receptor-mediated $\mathrm{G}$ protein signalling with high efficiency.

Previous studies have described partial agonist effects of NDMC at the cloned $\mathrm{M}_{1}-\mathrm{M}_{5}$ muscarinic receptors (Sur et al, 2003; Weiner et al, 2004; Davies et al, 2005) and $\mathrm{D}_{2}$ and $\mathrm{D}_{3}$ DA receptors (Burstein et al, 2005) with potencies generally comparable to those observed in $\mathrm{CHO} / \mathrm{DOR}$ cells $\left(\mathrm{pEC}_{50}\right.$ 

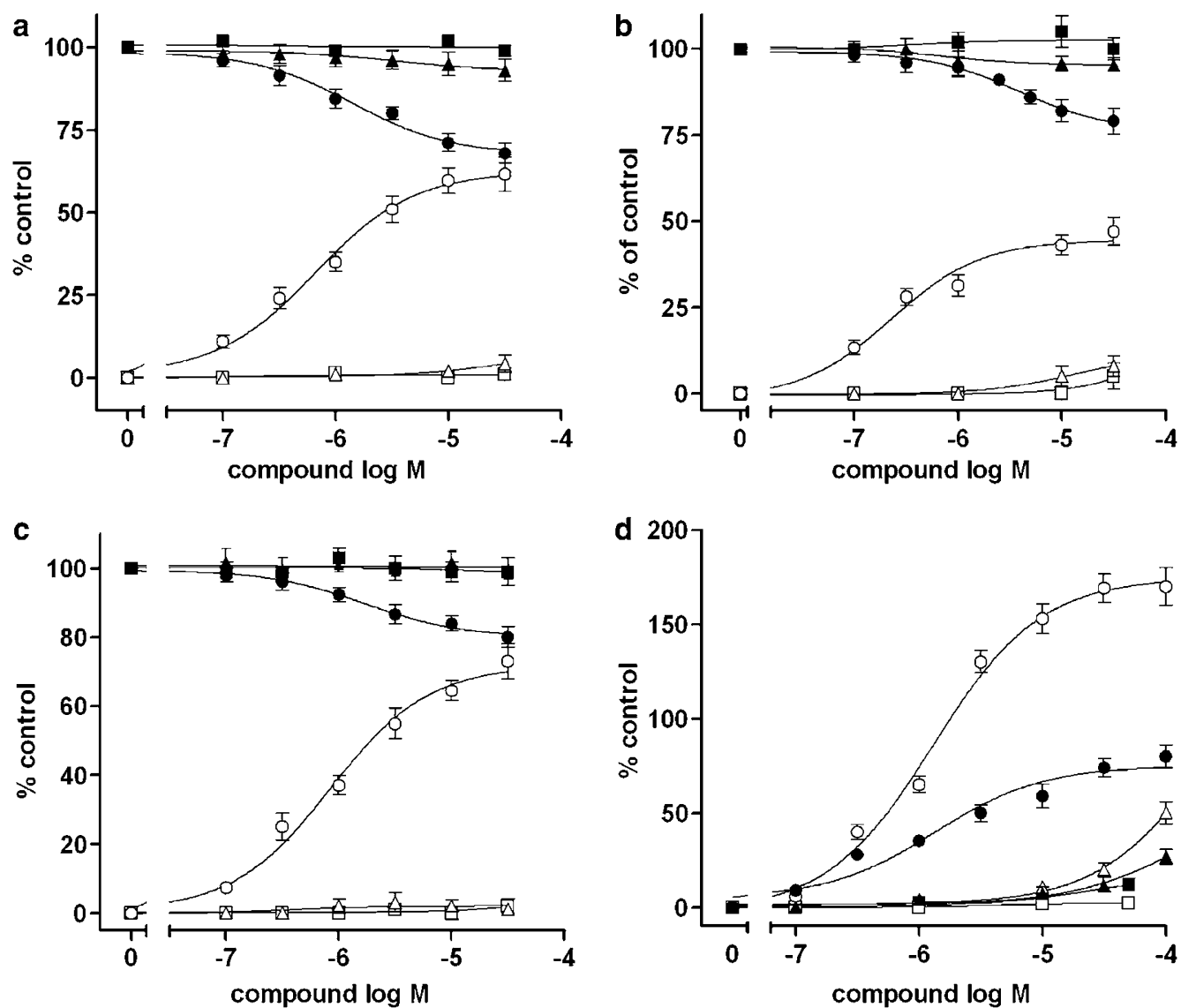

Figure 6 Concentration-dependent effects of NDMC (circles), clozapine (triangles), and CNOX (squares) on either $\left.{ }^{35} \mathrm{~S}\right] \mathrm{GTP} \gamma \mathrm{S}$ binding (open symbols) or adenylyl cyclase activity (closed symbols) in membranes of dorsal striatum (a), nucleus accumbens (b), frontal cortex (c), and granule cell layer of main olfactory bulb (d). For $\left[{ }^{35} \mathrm{~S}\right] \mathrm{GTP} \gamma \mathrm{S}$ binding assays, tissue membranes (3-4 $\mu \mathrm{g}$ of protein) were preincubated in the presence of the indicated concentrations of each drug for $20 \mathrm{~min}$ at $30^{\circ} \mathrm{C}$. Thereafter, the reaction was started by the addition of I nM $\left.{ }^{35} \mathrm{~S}\right] \mathrm{GTP} \gamma \mathrm{S}$ and continued for 40 min. Adenylyl cyclase activity was assayed in the presence of $10 \mu \mathrm{M}$ FSK in dorsal striatum, nucleus accumbens and frontal cortex, and under basal condition in olfactory bulb granule cell layer. Values are reported as percent of control and are the mean \pm SEM of three to four experiments.

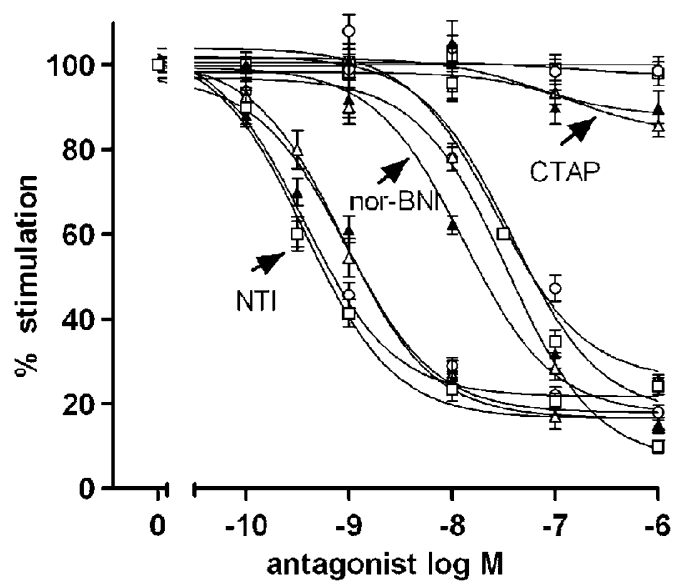

Figure 7 Antagonism of NDMC-induced stimulation of $\left[{ }^{35} \mathrm{~S}\right] \mathrm{GTP} \gamma \mathrm{S}$ binding in different rat brain regions by NTI, nor-binaltorphimine (nor-BNI), and CTAP. Membranes of dorsal striatum (open triangles), nucleus accumbens (closed triangles), frontal cortex (circles), and olfactory bulb granule cell layer (squares) were preincubated in the presence of $10 \mu \mathrm{M}$ NDMC and the indicated concentrations of the opioid receptor antagonists for $20 \mathrm{~min}$ at $30^{\circ} \mathrm{C}$. Thereafter, the reaction was started by the addition of I nM $\left.{ }^{35} \mathrm{~S}\right] \mathrm{GTP} \gamma \mathrm{S}$ and continued for $40 \mathrm{~min}$. Values are reported as percent of NDMC stimulation at each antagonist concentration and are the mean \pm SEM of three determinations. At the indicated concentrations, each antagonist per se failed to affect basal $\left[{ }^{35} \mathrm{~S}\right] \mathrm{GTP} \gamma \mathrm{S}$ binding. values $=7.24-6.40)$. For instance, in cells expressing $M_{1}$ muscarinic receptors NDMC stimulated intracellular $\mathrm{Ca}^{2+}$ levels with $\mathrm{pEC}_{50}$ values of 7.65 (Davies et al, 2005) and of 6.94 (Sur et al, 2003) and phosphoinositide hydrolysis with a $\mathrm{pEC}_{50}$ of 6.7 (Weiner et al, 2004). At $\mathrm{D}_{2}$ and $\mathrm{D}_{3} \mathrm{DA}$ receptors, NDMC displayed agonist activity equal to 35 and $50 \%$ of that of pergolide at the concentration of 20 and $30 \mathrm{nM}$, respectively (Burstein et al, 2005). NDMC displayed higher potency $\left(K_{\mathrm{i}}=2.9 \mathrm{nM}\right)$ in antagonizing $5-\mathrm{HT}_{2 \mathrm{C}}$ receptor-mediated phosphoinositide hydrolysis in rat choroid plexus and $\left[{ }^{3} \mathrm{H}\right]$ ketanserin binding to $5-\mathrm{HT}_{2 \mathrm{~A}}$ in rat frontal cortex $\left(K_{\mathrm{i}}=7.4 \mathrm{nM}\right)$ (Kuoppamaki et al, 1993).

Clozapine displayed an agonist activity similar to that of its demethylated metabolite, being active in CHO/DOR cells but having little effects in CHO/KOR, MOR-1, and NOP cells. However, as $\delta$-opioid receptor agonist, clozapine was much weaker than NDMC. Thus, clozapine affected $\left[{ }^{35} \mathrm{~S}\right] \mathrm{GTP} \gamma \mathrm{S}$ binding and cyclic AMP accumulation with $\mathrm{pEC}_{50}$ values that were 18 -fold lower than those of the demethylated metabolite. A similar difference was observed between the $\mathrm{p} K_{\mathrm{i}}$ values of the two drugs for the high-affinity binding site at the $\delta$-opioid receptor. Moreover, the calculated $K_{\mathrm{i}} / \mathrm{EC}_{50}$ ratio of clozapine in stimulating $\left[{ }^{35} \mathrm{~S}\right] \mathrm{GTP} \gamma \mathrm{S}$ binding was half of that of NDMC and the estimated efficacy value corresponded to only one-third of 
that displayed by DPDPE, suggesting that the drug activates the $\delta$-opioid receptor with a relatively low efficiency. The finding that clozapine possesses agonist activity at the $\delta$ opioid receptor is in agreement with a previous study by Kobayashi et al (1998), who reported that in Xenopus oocytes co-injected with the G-protein-activated inwardly rectifying potassium channel and either the $\delta$ - or $\kappa$-opioid receptor mRNA, clozapine stimulated the $\delta$-opioid receptor more potently and efficaciously $\left(\mathrm{EC}_{50}=4.56 \mu \mathrm{M}\right.$; $60 \%$ of the DPDPE response) than the $\kappa$-opioid receptor $\left(\mathrm{EC}_{50}=30.2 \mu \mathrm{M} ; 20 \%\right.$ of the $\mathrm{U}-50,488 \mathrm{H}$ response).

Differently from NDMC and clozapine, CNOX was a poor agonist at the $\delta$-opioid receptor and failed to affect the other opioid receptor subtypes. Moreover, in competition binding assays, the compound inhibited the $\left[{ }^{3} \mathrm{H}\right] \mathrm{NTI}$ binding to $\mathrm{CHO} / \mathrm{DOR}$ cell membranes with low affinity and in a guanine nucleotide-insensitive manner, a property typical of receptor antagonist. Indeed, $\mathrm{CNOX}$ showed a $K_{\mathrm{i}} / \mathrm{EC}_{50}$ ratio close to unity and an estimated efficacy value less than $1 \%$ of that shown by DPDPE, indicating that the compound possesses a very low intrinsic activity.

As heterologous cell lines overexpressing the cloned receptors provide a system with a high stimulus-response efficiency that may greatly affect agonist intrinsic activity, it was important to investigate whether NDMC was able to activate the $\delta$-opioid receptor in cell systems expressing receptors, $G$ proteins, and effectors under native conditions. We found that in NG108-15 cells, which endogenously express $\delta$-opioid receptors (Evans et al, 1992), NDMC inhibited FSK-stimulated cyclic AMP accumulation as effectively as DPDPE, clozapine was 25-fold less potent and significantly less efficacious, and CNOX was completely inactive. The involvement of the $\delta$-opioid receptor in the NDMC response was demonstrated by the complete and potent blockade by NTI. Moreover, in the same cell system, NDMC induced ERK1/2 phosphorylation by acting at the $\delta$ opioid receptor, as previously observed for other opioid agonists (Zhang et al, 1999). In neuronal cells, ERK1/2 is known to participate in molecular pathways regulating learning, memory, and synaptic plasticity (Thomas and Hunganir, 2004). Previously, it has been reported that in mice the systemic administration of NDMC increased phospho-ERK1/2 immunoreactivity in the hippocampus and this response was blocked by pretreatment with scopolamine, indicating the participation of muscarinic receptors (Weiner et al, 2004). Studies in rats have shown that clozapine induced ERK1/2 phosphorylation in prefrontal cortex by blocking serotonin $5 \mathrm{HT}_{2 \mathrm{~A}}$ receptors and that ERK1/2 inhibitors prevented clozapine suppression of the conditioned avoidance response, a behavioral index of antipsychotic activity (Browning et al, 2005). It will be of interest to investigate whether in the brain NDMC can regulate ERK1/2 activity via $\delta$-opioid receptors as found in NG108-15 cells.

The ability of NDMC to activate native $\delta$-opioid receptor was also examined in distinct rat brain areas, such as dorsal striatum, nucleus accumbens, frontal cortex, and the granule cell layer of main olfactory bulb, which express high to intermediate concentrations of $\delta$ receptors together with other opioid receptors (Mansour et al, 1995). In each brain area, NDMC stimulated $\left[{ }^{35} \mathrm{~S}\right] \mathrm{GTP} \gamma \mathrm{S}$ binding and regulated cyclic AMP formation in a manner qualitatively similar to $\delta$-opioid receptor agonists. The maximal stimulations of $\left[{ }^{35} \mathrm{~S}\right] \mathrm{GTP} \gamma \mathrm{S}$ binding by NDMC ranged from 75 to $100 \%$ of that of DPDPE and were potently blocked by NTI, but not by nor-BNI or CTAP. Moreover, NDMC had little effects in membranes of rat thalamus, which expresses a high concentration of $\mu$-opioid receptors and a low level of $\delta$ receptors (Mansour et al, 1995). These data indicate that NDMC retains the ability to activate $\delta$-opioid receptors endogenously expressed in brain. It is noteworthy that in the brain membrane preparations clozapine displayed negligible agonist activity, in agreement with the low efficacy value showed in CHO/DOR cells.

While in CHO/DOR cells NDMC stimulated $\left[{ }^{35} \mathrm{~S}\right] \mathrm{GTP} \gamma \mathrm{S}$ binding with a nanomolar potency, the compound was significantly less potent in activating the native $\delta$-opioid receptor with $\mathrm{pEC}_{50}$ values ranging from 5.73 to 6.18 . Nonetheless, these values are within the range of NDMC plasma concentrations $(175-435 \mathrm{ng} / \mathrm{ml} ; 0.6-1.4 \mu \mathrm{M})$ measured in schizophrenics following chronic treatment with clozapine (Centorrino et al, 1994; Olesen et al, 1995; Aravagiri and Marder, 2001; Frazier et al, 2003). The concentrations reached by NDMC in the human brain under these conditions are unknown. Studies in rats have reported that brain levels of NDMC were relatively low as compared to those of clozapine (Baldessarini et al, 1993). However, in the study of Weigmann et al (1999), who analyzed the blood/brain distribution of clozapine and NDMC under steady-state conditions, the brain levels of NDMC reached a value of $2000 \mathrm{ng} / \mathrm{g}$ and were about threefold lower that those of clozapine. Although these values do not allow the determination of the drug concentrations in the biophase, they are comparable with the potencies of NDMC in activating the $\delta$-opioid receptor in rat brain membranes. Moreover, whereas clozapine has higher affinity than NDMC at muscarinic $\mathrm{M}_{1}$ and $\mathrm{DA} \mathrm{D}_{2} / \mathrm{D}_{3}$ receptors and potently antagonizes NDMC agonist activity at these receptors (Sur et al, 2003; Weiner et al, 2004; Burstein et al, 2005; Li et al, 2005), the affinity of clozapine for the $\delta$-opioid receptor is more than 10 -fold lower than that of NDMC, suggesting that in the brain the demethylated metabolite could activate the receptors even in the presence of higher concentrations of the parent drug.

Clinical studies on the role of opioids in schizophrenia have yielded conflicting results, as some investigations reported beneficial effects with either opioid agonists (Brizer et al, 1985; Schmauss et al, 1987) or antagonists (Berger et al, 1981; Marchesi et al, 1995), whereas others observed either impairment of schizophrenic symptoms (Gerner et al, 1980; Judd and Janowsky, 1981) or no effects (Naber, 1988; Wonodi et al, 2004) with similar treatments. Moreover, most of the studies employed nonselective agents, making the understanding of the role of each opioid receptor difficult. Thus, at present the relevance of the selective $\delta$-opioid agonist activity of NDMC for the antipsychotic action of clozapine remains uncertain. Nonetheless, it is possible that this property may have implications for clozapine activity in mood disorders. A number of evidence from animal studies indicate that $\delta$-opioid receptors are highly expressed in cortical and limbic regions and are involved not only in analgesia, but also in the control of cognitive and emotional functions and motivation-related behaviors. Mice deficient in pre-proen- 
kephalin, which generates the $\delta$-preferring agonists enkephalins, showed increased levels of anxiety and males displayed offensive aggressiveness (Konig et al, 1996). Moreover, mice, in which the $\delta$-opioid receptor gene has been disrupted by targeted deletion of exon 1, exhibited anxiogenic effects in the elevated-plus-maze and the lightdark box behavioral tests, whereas $\mu$-opioid receptor deficient mice showed anxiolytic effects (Filliol et al, 2000). Importantly, mice lacking the $\delta$-opioid receptors exhibited a depressive-like behavior in tests that reliably predict antidepressant effects in humans (Filliol et al, 2000). Thus, it can be proposed that an increased $\delta$-opioid receptor activity by NDMC may contribute, at least in part, to the reported clinical efficacy of clozapine in ameliorating psychotic mood disorders (McElroy et al, 1991), in reducing the risk of suicide in schizophrenia and schizoaffective disorder (Meltzer et al, 2003; Kerwin and Bolonna, 2004) and in suppressing aggressive behaviors in psychotic patients (Kraus and Sheitman, 2005). A relevant role of $\delta$ opioid receptors in depression is further supported by pharmacological data showing that the nonpeptidic $\delta$ opioid receptor agonists ( + )BW373U86 and SNC80 exerted antidepressive effects in animal models (Broom et al, 2002) and potentiated $D_{1}$ and $D_{2}$ DA receptor stimulation (Spina et al, 1998), which may improve cognition and depression, and that, conversely, $\delta$-opioid receptor antagonists caused anxiety-related behaviors (Saito et al, 2005). Like antidepressant drugs (Nibuya et al, 1995), $\delta$-opioid receptor agonists have been found to increase the hippocampal and cortical synthesis of brain-derived neurotrophic factor (BDNF) (Torregrossa et al, 2004), which is known to regulate neuronal development and plasticity and has been shown to possess antidepressant activity (Shirayama et al, 2002). Finally, selective activation of $\delta$-opioid receptor has been shown to reverse the catalepsy induced by DA receptor antagonists and the parkinsonian symptoms in the MPTPtreated marmoset (Hille et al, 2001) and to cause convulsions (Comer et al, 1993), a relatively frequent side effect of clozapine therapy.

In conclusion, the present study demonstrates that NDMC behaves as a selective and efficacious $\delta$-opioid agonist in recombinant and native receptor systems. This unique property provides the compound with the ability to affect those molecular pathways and neuronal circuits of the central opioid system specifically involved in the control of emotion and motivation and therefore may contribute to important features of the clozapine therapeutic action, particularly in improving mood disorders.

\section{ACKNOWLEDGEMENTS}

We thank the University of Missouri-Rolla cDNA Resource Center (www.cdna.org) for providing the cDNAs encoding the human opioid receptors.

\section{REFERENCES}

Angulo JA, Cadet JL, Woolley CS, Suber F, McEwen B (1990). Effect of chronic typical and atypical neuroleptic treatment on proenkephalin mRNA levels in the striatum and nucleus accumbens of the rat. J Neurochem 54: 1889-1894.
Aravagiri M, Marder SR (2001). Simultaneous determination of clozapine and its $\mathrm{N}$-desmethyl and $\mathrm{N}$-oxide metabolites in plasma by liquid chromatography/electrospray tandem mass spectrometry and its application to plasma level monitoring in schizophrenic patients. J Pharm Biomed Anal 26: 301-311.

Baldessarini RJ, Centorrino F, Flood JG, Volpicelli SA, HustonLyons D, Cohen BM (1993). Tissue concentrations of clozapine and its metabolites in the rat. Neuropsychopharmacology 9: 117-124.

Berger PA, Watson SJ, Akil H, Barchas JD (1981). The effects of naloxone in chronic schizophrenia. Am J Psychiatry 138: 913-918.

Bradford MM (1976). A rapid and sensitive method for the quantitation of microgram quantities of protein utilizing the principle of protein-dye binding. Anal Biochem 72: 248-254.

Brizer DA, Hartman N, Sweeney J, Millman RB (1985). Effect of methadone plus neuroleptics on treatment-resistant chronic paranoid schizophrenia. Am J Psychiatry 142: 1106-1107.

Broom DC, Jutkiewicz EM, Folk JE, Traynor JR, Rice KC, Woods JH (2002). Nonpeptidic $\delta$-opioid receptor agonists reduce immobility in the forced swim assay in rats. Neuropsychopharmacology 26: 744-755.

Browning JL, Patel T, Brandt PC, Young KA, Holcomb LA, Hicks PB (2005). Clozapine and the mitogen-activated protein kinase signal transduction pathway: implication for antipsychotic actions. Biol Psychiatry 57: 617-623.

Burstein ES, Ma J, Wong S, Gao Y, Pham E, Knapp AE et al (2005). Intrinsic efficacy of antipsychotics at human D2, D3 and D4 dopamine Receptors: identification of the clozapine metabolite $\mathrm{N}$-desmethylclozapine as $\mathrm{D}_{2} / \mathrm{D}_{3}$ partial agonist. J Pharmacol Exp Ther 315: 1278-1287.

Centorrino F, Baldessarini RJ, Kando JC, Frankenburg FR, Volpicelli SA, Flood JG (1994). Clozapine and metabolites: concentrations in serum and clinical findings during treatment of chronically psychotic patients. J Clin Psychopharmacol 14: 119-125.

Cheng YC, Prusoff WH (1973). Relationship between the inhibition constant $\left(K_{\mathrm{i}}\right)$ and the concentration of inhibitor which causes 50 percent inhibition $\left(\mathrm{I}_{50}\right)$ of an enzymatic reaction. Biochem Pharmacol 22: 3099-3102.

Comer SD, Hoenicke EM, Sable AI, McNutt RW, Chang K-J, DeCosta BR et al (1993). Convulsive effects of systemic administration of the delta opioid agonist BW373U86 in mice. J Pharmacol Exp Ther 267: 888-895.

Davies MA, Compton-Toth BA, Hufeisen SJ, Meltzer HY, Roth BL (2005). The highly efficacious actions of $\mathrm{N}$-desmethylclozapine at muscarinic receptors are unique and not a common property of either typical or atypical antipsychotic drugs: is M1 agonism a pre-requisite for mimicking clozapine's actions ? Psychopharmacology 178: 451-460.

Ehlert FJ (1985). The relationship between muscarinic receptor occupancy and adenylate cyclase inhibition in the rabbit myocardium. Mol Pharmacol 28: 410-421.

Evans CJ, Keith Jr DE, Morrison H, Magendzo K, Edwards RH (1992). Cloning of a delta opioid receptor by functional expression. Science 258: 1952-1955.

Filliol D, Ghozland S, Chluba J, Martin M, Matthes HWD, Simonin $\mathrm{F}$ et al (2000). Mice deficient for $\delta$ - and $\mu$-opioid receptors exhibit opposing alterations of emotional responses. Nat Genet 25: 195-200.

Fleming WW, Westfall DP, De La Lande S, Jellet LB (1972). Lognormal distribution of equieffective doses of norepinephrine and acetylcholine in several tissues. J Pharmacol Exp Ther 181: 339-345.

Frazier JA, Glassner Cohen L, Jacobson L, Grothe D, Flood J, Baldessarini RJ et al (2003). Clozapine pharmacokinetics in children and adolescents with childhood-onset schizophrenia. J Clin Psychopharmacol 23: 87-91. 
Gerner RM, Catlin DH, Gorelick DA, Hui KK, Li CH (1980). Endorphin. Intravenous infusion causes behavioural changes in psychiatric inpatients. Arch Gen Psychiatry 37: 642-647.

Gulya K (1990). The opioid system in neurologic and psychiatric disorders and their experimental models. Pharmacol Ther 46: 395-428.

Hille CJ, Fox SH, Maneuf YP, Crossman AR, Brotchie JM (2001). Antiparkinsonian actions of a delta opioid agonist in rodent and primate models of Parkinson's disease. Exp Neurol 172: 189-198.

Judd LL, Janowsky DS (1981). Effects of narcotics and narcotic antagonists on affective disorders, schizophrenia and serum hormones. Mod Probl Pharmacopsychiatry 17: 213-225.

Kerwin RW, Bolonna AA (2004). Is clozapine antisuicidal? Expert Rev Neurother 4: 187-190.

Kobayashi T, Ikeda K, Kumanishi T (1998). Effects of clozapine on the $\delta$ - and $\kappa$-opioid receptors and the G-protein-activated $\mathrm{K}^{+}$ (GIRK) channel expressed in Xenopus oocytes. Br J Pharmacol 123: 421-426.

Konig M, Zimmer AM, Steiner H, Holmes PV, Crawley JN, Brownstein MJ et al. (1996). Pain responses, anxiety and aggression in mice deficient in pre-proenkephalin. Nature 383: 535-538.

Kraus JE, Sheitman BB (2005). Clozapine reduces violent behavior in heterogeneous diagnostic groups. J Neuropsychiatry Clin Neurosci 17: 36-44.

Kuoppamaki M, Syvalahti E, Hietala J (1993). Clozapine and $\mathrm{N}$-desmethylclozapine are potent $5-\mathrm{HT}_{1 \mathrm{c}}$ receptor antagonists. Eur J Pharmacol Mol Pharmacol Sect 245: 179-182.

Li Z, Huang M, Ichikawa J, Dai J, Meltzer HY (2005). NDesmethylclozapine, a major metabolite of clozapine, increases cortical acethylcholine and dopamine release in vivo via stimulation of M1 muscarinic receptors. Neuropsychopharmacology 30: 1986-1995.

Mansour A, Fox CA, Akil H, Watson SJ (1995). Opioid-receptor mRNA expression in the rat CNS: anatomical and functional implications. Trends Neurosci 18: 22-29.

Marchesi GF, Santone G, Cotani P, Giordano A, Chelli F (1995). The therapeutic role of naltrexone in negative symptom schizophrenia. Prog Neuropsychopharmacol Biol Psychiatry 19: 1239-1249.

McElroy SL, Dessain EC, Pope Jr HG, Cole JO, Keck Jr PE, Frankenberg FR et al (1991). Clozapine in the treatment of psychotic mood disorders, schizoaffective disorder, and schizophrenia. J Clin Psychiatry 52: 411-414.

Meltzer HY (2002). Mechanism of action of atypical antipsychotic drugs. In: Davis KL, Charney D, Coyle JT, Nemeroff C (eds). Neuropsychopharmacology: The Fifth Generation of Progress. Lippincott Williams \& Wilkins: Philadelphia. pp 819-831.

Meltzer HY, Alphs L, Green AI, Altamura AC, Anand R, Bertoldi A et al (2003). Clozapine treatment for suicidality in schizophrenia: International Suicide Prevention Trial (InterSePT). Arch Gen Psychiatry 60: 82-91.

Michal P, Lysikova M, El-Fakahany E, Tucek S (1999). Clozapine interaction with the M2 and M4 subtypes of muscarinic receptors. Eur J Phamacol 376: 119-125.

Munson PJ, Rodbard D (1980). Ligand: a versatile computerized approach for the characterization of ligand binding systems. Anal Biochem 107: 220-239.

Naber D (1988). Clinical relevance of endorphins in psychiatry. Prog Neuropsychopharmacol Biol Psychiatry 12(Suppl): S119-S135.

Nibuya M, Morinobu S, Duman RS (1995). Regulation of BDNF and trkB mRNA in rat brain by chronic electroconvulsive seizure and antidepressant drug treatments. J Neurosci 15: 7539-7547.

Olesen OV, Thomsen K, Jensen PN, Wulff CH, Rasmussen NA, Refshammer C et al (1995). Clozapine serum levels and side effects during steady state treatment of schizophrenic patients: a cross-sectional study. Psychopharmacology 117: 371-378.
Olianas MC, Maullu C, Onali P (1997). Effects of clozapine on rat striatal muscarinic receptors coupled to inhibition of adenylyl cyclase activity and on the human cloned $\mathrm{m} 4$ receptor. $\mathrm{Br}$ Pharmacol 122: 401-408.

Olianas MC, Maullu C, Onali P (1999). Mixed agonist-antagonist properties of clozapine at different human cloned muscarinic receptor subtypes expressed in Chinese hamster ovary cells. Neuropsychopharmacology 20: 263-270.

Onali P, Olianas MC (2002). Muscarinic $\mathrm{M}_{4}$ receptor inhibition of dopamine D1-like receptor signalling in rat nucleus accumbens. Eur J Pharmacol 448: 105-111.

Onali P, Olianas MC (2004a). Agonist activity of $\mathrm{N}$-desmethylclozapine at $\delta$-opioid receptors. Soc Neurosci Abstr 734.6.

Onali P, Olianas MC (2004b). G protein activation and cyclic AMP modulation by naloxone benzoylhydrazone in distinct layers of rat olfactory bulb. Br J Pharmacol 143: 638-648.

Pickar D, Naber D, Post RM, van Kammen DP, Kaye W, Rubinow DR et al (1982). Endorphins in the cerebrospinal fluid of psychiatric patients. Ann NY Acad Sci 398: 399-412.

Quock RM, Burkey TH, Varga E, Hosohata Y, Hosohata K, Cowell SM et al (1999). The $\delta$-opioid receptor: molecular pharmacology, signal transduction, and determination of drug efficacy. Pharmacol Rev 51: 503-532.

Roth BL, Sheffler DJ, Kroeze WK (2004). Magic shotguns versus magic bullets: selectively non-selective drugs for mood disorders and schizophrenia. Nat Rev Drug Discov 3: 353-359.

Saito A, Yoshikawa Y, Onodera K, Kamei J (2005). Role of $\delta$-opioid receptor subtypes in anxiety-related behaviours in the elevated plus-maze in rats. Psychopharmacology 182: 327-334.

Schmauss C, Emrich HM (1985). Dopamine and the action of opiates: a reevaluation of the dopamine hypothesis of schizophrenia. With special consideration of the role of endogenous opioids in the pathogenesis of schizophrenia. Biol Psychiatry 20: 1211-1231.

Schmauss C, Yassouridis A, Emrich HM (1987). Antipsychotic effect of buprenorphine in schizophrenia. Am J Psychiatry 144: $1340-1342$.

Schreiber S, Getslev V, Backer MM, Weizman R, Pick CG (1999). The atypical neuroleptics clozapine and olanzapine differ regarding their antinociceptive mechanism and potency. Pharmacol Biochem Behav 64: 75-80.

Shirayama Y, Chen AC-H, Nakagawa S, Russell DS, Duman RS (2002). Brain-derived neurotrophic factor produces antidepressant effects in behavioural models of depression. J Neurosci 22: $3251-3261$

Somoza E, Franco C, Lavina M, Fuentes JA (1981). Clozapine inhibition of met-enkephalin binding to synaptosome-enriched fractions of rat whole brain and hippocampus. Neurochem Res 6: $413-424$

Spina L, Longoni R, Mulas A, Chang K-J, Di Chiara G (1998). Dopamine-dependent behavioural stimulation by non-peptide delta opioids BW373U86 and SNC 80: 1. Locomotion, rearing and stereotypies in intact rats. Behav Pharmacol 9: 1-8.

Sur C, Mallorga PJ, Wittmann M, Jacobson MA, Pescarella D, Williams JB et al (2003). $N$-desmethylclozapine, an allosteric agonist at muscarinic 1 receptor, potentiates $N$-methylD-aspartate receptor activity. Proc Natl Acad Sci USA 100 13674-13679.

Thomas GM, Hunganir RL (2004). MAPK cascade signalling and synaptic plasticity. Nat Rev Neurosci 5: 173-183.

Torregrossa MM, Isgor C, Folk JE, Rice KC, Watson SJ, Woods JH (2004). The $\delta$-opioid receptor agonist $(+) B W 373$ U86 regulates BDNF mRNA expression in rats. Neuropsychopharmacology 29: 649-659.

Towbin H, Staehelin T, Gordon J (1979). Electrophoretic transfer of proteins from polyacrylamide gels to nitrocellulose sheets: procedure and some applications. Proc Natl Acad Sci USA 76 $4350-4354$ 
Weigmann H, Hartter S, Fischer V, Dahmen N, Hiemke C (1999). Distribution of clozapine and desmethylclozapine between blood and brain in rats. Eur Neuropsychopharmacology 9: 253-256.

Weiner DM, Meltzer HY, Veinbergs I, Donohue EM, Spalding TA, Smith TT et al (2004). The role of M1 muscarinic receptor agonism of $\mathrm{N}$-desmethylclozapine in the unique clinical effects of clozapine. Psychopharmacology 177: 207-216.

Werling LL, Puttfarcken PS, Cox BM (1988). Multiple agonistaffinity states of opioid receptors: regulation of binding by guanyl nucleotides in guinea pig cortical, NG108-15, and 7315c cell membranes. Mol Pharmacol 33: 423-431.

Wonodi I, Adami H, Sherr J, Avila M, Hong LE, Thaker GK (2004). Naltrexone treatment of tardive dyskinesia in patients with schizophrenia. J Clin Psychopharmacol 24: 441-445.

Young CD, Meltzer HY, Deutch AY (1998). Effects of desmethylclozapine on fos protein expression in the forebrain: in vivo

biological activity of the clozapine metabolite. Neuropsychopharmacology 19: 99-103.

Zang S-P, Connell TA, Price T, Simpson GM, Zhou L-W, Weiss B (1995). Continuous infusion of clozapine increases mu and delta opioid receptors and proenkephalin mRNA in mouse brain. Biol Psychiatry 37: 496-503.

Zeng XP, Le F, Richelson E (1997). Muscarinic m4 receptor activation by some atypical antipsychotic drugs. Eur J Pharmacol 321: 349-354.

Zhang Z, Xin S-M, Wu G-X, Zhang W-B, Ma L, Pei G (1999). Endogenous $\delta$-opioid and ORL1 receptors couple to phosphorylation and activation of p38 MAPK in NG108-15 cells and this is regulated by protein kinase A and protein kinase C. $J$ Neurochem 73: 1502-1509.

Zorn SH, Jones SB, Ward KM, Liston DR (1994). Clozapine is a potent and selective muscarinic M4 receptor agonist. Eur J Pharmacol-Mol Pharmacol Sect 269: R1-R2. 